Check for updates

Cite this: RSC Adv., 2018, 8, 13205

Received 21st December 2017 Accepted 28th March 2018

DOI: $10.1039 / c 7 r a 13540 h$

rsc.li/rsc-advances

\title{
Lead and uranium sorptive removal from aqueous solution using magnetic and nonmagnetic fast pyrolysis rice husk biochars
}

\author{
Shujuan Wang, ${ }^{a}$ Wei Guo, (iD *ac Fan Gao, ${ }^{\text {b }}$ Yunkai Wang ${ }^{a}$ and Yue Gaoc
}

\begin{abstract}
This paper discusses the sorption characteristics of $\mathrm{Pb}(\|)$ and $\mathrm{U}(\mathrm{VI})$ on magnetic and nonmagnetic rice husk biochars. The porosity, specific surface area, hydrophobility, and reusability of biochar were effectively improved (1-2 times) after magnetic modification. The optimum adsorption conditions were as follows: biochar loading was $0.4 \mathrm{~g} \mathrm{~L}^{-1}, \mathrm{pH}$ value was 7.0, and anion strength of $\mathrm{NO}_{3}^{-}$and $\mathrm{PO}_{4}{ }^{3-}$ were $0.01 \mathrm{~mol} \mathrm{~L}^{-1}$ for $\mathrm{Pb}(\|)$ and $0.04 \mathrm{~mol} \mathrm{~L}^{-1}$ for $\mathrm{U}(\mathrm{VI})$ respectively. Compared with $\mathrm{U}(\mathrm{VI}), \mathrm{Pb}(॥)$ had the faster adsorption rate and higher adsorption capacity on magnetic biochar (MBC). The adsorption experimental data were well fitted by pseudo-second-order kinetic and Langmuir isotherm models. The maximum adsorption capacity of $\mathrm{Pb}(\mathrm{I})$ and $\mathrm{U}(\mathrm{VI})$ on $\mathrm{MBC}$ was 129 and $118 \mathrm{mg} \mathrm{g}^{-1}$ at $328 \mathrm{~K}$ respectively, which was significantly higher than that of other sources biochars. $\mathrm{Pb}(\Perp)$ was mainly bonded to biochar by physisorption but the adsorption of $\mathrm{U}(\mathrm{vl})$ on biochar was mostly chemisorption. Fe oxides in MBC noticeably improved the ion exchange and complexation action between biochar and metal ion especially for $U(\mathrm{VI})$. The experimental results confirmed MBC material can be used as a cost-effective adsorbent for the removal of $\mathrm{Pb}(\|)$ and $\mathrm{U}(\mathrm{VI})$ and can be separated easily from aqueous solution when application.
\end{abstract}

\section{Introduction}

The rapid development experienced by the mining, metal smelting, electroplating, chemical engineering, and energy field industries in recent decades has led to serious environmental and health problems caused by heavy metals, especially in the industrialized areas of developing countries. ${ }^{1}$ China is the largest lead producer and consumer. ${ }^{2}$ Consequently, large amounts of wastewaters containing $\mathrm{Pb}(\mathrm{II})$ were inevitably discharged into the aquatic environment of some places, causing negative effects such as elevated blood lead levels to numerous people. ${ }^{3}$ Moreover, China is a big country that is currently developing and using nuclear energy (130 $580 \mathrm{GWh}, 3 \%$ of the world nuclear power). ${ }^{4}$ Thus, nuclear radioactive elements such as $\mathrm{U}(\mathrm{vI})$ can be potentially discharged to the aquatic environment, and public health problems can be produced as a result of uranium mining and processing activities.

$\mathrm{Pb}$ (II) and $\mathrm{U}(\mathrm{VI})$ are highly toxic heavy metals that can cause adverse damage on the ecosystem and human health at low

${ }^{a}$ School of Environmental Science and Engineering, North China Electric Power University, Beinong Road 2, Beijing 102206, China. E-mail: gwfybj@ncepu.edu.cn; Fax: +8610 61773936; Tel: +861061773936

${ }^{b}$ Beijing Key Laboratory of New Technique in Agricultural Application, Beijing University of Agriculture, Beinong Road 2, Beijing 102206, China

${ }^{c}$ Analytical, Environmental and Geo-Chemistry, Vrije Universiteit Brussel, Pleinlaan 2, Brussel 1050, Belgium concentrations. ${ }^{5-8}$ Therefore, considering the toxicity and the associated environmental and health risks of $\mathrm{Pb}(\mathrm{II})$ and $\mathrm{U}(\mathrm{vI})$, along with their production and usage, the separation and removal of $\mathrm{Pb}(\mathrm{II})$ and $\mathrm{U}(\mathrm{VI})$ from wastewaters have become urgent tasks in China and similar developing countries. According to the drinking water quality standard specified in the World Health Organization (WHO) guidelines, the maximum acceptable concentrations of $\mathrm{Pb}(\mathrm{II})$ and $\mathrm{U}(\mathrm{VI})$ in drinking water should be lower than 10 and $15 \mu \mathrm{g} \mathrm{L}^{-1}$, respectively. ${ }^{\mathbf{9}, 10}$ With the aim to meet these stringent permissible $\mathrm{Pb}$ (II) and $\mathrm{U}(\mathrm{vI})$ limits, water treatment utilities are required to upgrade their current technology or consider new purification techniques.

Different methods including precipitation, evaporation, ionexchange, photocatalytic processes, reverse osmosis, coagulation-flocculation, ultrafiltration, and adsorption have been developed to treat $\mathrm{Pb}(\mathrm{II})$ and $\mathrm{U}(\mathrm{VI})$ from the aqueous solution. ${ }^{3,8}$ Among these existing methods, adsorption has become one of the most promising the effective techniques due to its better performance, easy operation, and low cost. Thus, much effort has been spent developing inexpensive, environmental-friendly and higher effective adsorbents for the removal of toxic heavy metals. ${ }^{11}$ For example, $\mathrm{Pb}$ (II) maximum adsorption capacities of $81.78 \mathrm{mg} \mathrm{g}^{-1}$ was determined for magnetic hydrogel beads, ${ }^{12}$ and the maximum sorption capacity of $\mathrm{UO}_{2}{ }^{2+}$ on poly(vinyl phosphonic acid) reached $900 \mathrm{mg} \mathrm{g}^{-1}$ at $\mathrm{pH} 6 .{ }^{13}$ Compared with these polymeric and commercial adsorbents, biochar, as a kind 
of biosorbents for heavy metals removal, has attracted much attention due to their special advantages of environmentally benign nature, low replacement cost, and practical application in a large scale. ${ }^{\mathbf{1 4 - 1 6}}$ However, when directly applying these pristine biochars (BC) to wastewater treatment, the adsorption capacity and removal efficiency of pollutants on pristine biochar easily declined with the change of environmental factors such as $\mathrm{pH}$, anion concentration, and temperature due to the structural and functional variation of biochar. ${ }^{17,18}$ Moreover, pristine biochar powders are difficult to separate from aqueous solutions after the removal treatment, thereby causing a secondary pollution problem. ${ }^{19,20}$ Previous studies have shown that a magnetic modification of biochar via aqueous $\mathrm{Fe}^{2+} / \mathrm{Fe}^{3+}$ solution or natural hematite treatments can effectively overcome these drawbacks. ${ }^{21}$ Thus, magnetic modification of biochars resulted in enhanced efficiencies towards the adsorption of some metals such as $\mathrm{Cd}(\mathrm{II}), \mathrm{Cr}$ (III), $\mathrm{Pb}$ (II), and $\mathrm{As}$ (III) while facilitating the recovery of the solid from the contaminated water via a filtration process with a magnet. ${ }^{22-25}$

Despite these novel studies, the adsorption mechanism and the behavior of magnetic biochar-adsorbed $\mathrm{Pb}(\mathrm{II})$ and $\mathrm{U}(\mathrm{VI})$ in aqueous solutions under different influence factors (especially coexisting anions such as $\mathrm{PO}_{4}{ }^{3-}$ and $\mathrm{NO}_{3}{ }^{-}$) is not fully known. Additionally, studies on the adsorption characteristics of $\mathrm{U}(\mathrm{vI})$ on magnetic biochars (MBC) are particularly scarce in the literature. Considering this lack of knowledge, in the study, MBC were prepared from rice husk biochar, and the sorption efficiencies of $\mathrm{Pb}$ (II) and $\mathrm{U}(\mathrm{VI})$ on $\mathrm{MBC}$ were compared with that on $\mathrm{BC}$ under different experimental conditions using batch experiments, and the adsorption mechanisms of $\mathrm{Pb}$ (II) and $\mathrm{U}(\mathrm{VI})$ on BC and MBC were explored based on the analysis of biochar characterization. Finally, in view of a practical and sustainable application, the regeneration properties and stability of MBC were also investigated and evaluated. The study would offer a new alternative to transform biomass waste into a selective adsorbent for $\mathrm{Pb}$ (II) and $\mathrm{U}(\mathrm{VI})$ removal from aqueous solution and also broad the applicability of biochar-based material in environmental pollution cleanup.

\section{Materials and methods}

\section{Materials}

A magnetically modified biochar was prepared via an aqueous $\mathrm{Fe}^{3+}$ solution treatment and subsequently was used to remove aqueous $\mathrm{Pb}(\mathrm{II})$ and $\mathrm{U}(\mathrm{VI})$. Being inexpensive and abundantly available in China, ${ }^{26}$ rice husk was selected as a raw material to produce $\mathrm{BC}$ and $\mathrm{MBC}$ samples. Rice husk was obtained from the Carnival Farm Shop, Beijing, China. Stock solutions of $\mathrm{Pb}$ (II) and $\mathrm{U}(\mathrm{vI})\left(200 \mathrm{mg} \mathrm{L}^{-1}\right.$ ) were prepared by dissolving $0.320 \mathrm{~g}$ of $\mathrm{Pb}\left(\mathrm{NO}_{3}\right)_{2}$ and $0.333 \mathrm{~g}$ of $\mathrm{H}_{2} \mathrm{~N}_{2} \mathrm{O}_{8} \mathrm{U}$ in $1 \mathrm{~L}$ of ultrapure water, respectively. Subsequently, these stock solutions were further diluted to the required concentration $\left(40 \mathrm{mg} \mathrm{L}^{-1}\right)$ with ultrapure water before performing the adsorption experiments. The $\mathrm{pH}$ of the experimental solutions was adjusted by using $0.1 \mathrm{M} \mathrm{NaOH}$ or $\mathrm{HCl}$ solutions. $\mathrm{NaNO}_{3}$ and $\mathrm{Na}_{3} \mathrm{PO}_{4}$ stock solutions $\left(1 \mathrm{~mol} \mathrm{~L}^{-1}\right)$ were prepared by dissolving the corresponding solid chemicals in ultrapure water.

\section{Preparation of the magnetic biochar}

The rice husk was pyrolyzed to produce biochar at $773 \mathrm{~K}$ for $2 \mathrm{~h}$ in a tube furnace (SK-2.5-13, Beijing ZhongXing WeiYe Instrument Co., China) under a nitrogen flow rate of $10 \mathrm{~mL} \mathrm{~min}^{-1}$. The biochar was subsequently modified using hydrothermally synthesized magnetic iron oxide particles. As previously described by Trakal et al. ${ }^{23} 1 \mathrm{~g}$ of $\mathrm{FeSO}_{4} \cdot 7 \mathrm{H}_{2} \mathrm{O}$ was dissolved in $100 \mathrm{~mL}$ of water in a $500 \mathrm{~mL}$ beaker and a solution of $\mathrm{NaOH}$ $\left(1 \mathrm{~mol} \mathrm{~L}^{-1}\right)$ was slowly added under mixing until the $\mathrm{pH}$ value reached ca. 12.0. The suspension was subsequently water diluted to $200 \mathrm{~mL}$ and maintained at constant temperature (353 $\mathrm{K}$, water bath) for $2 \mathrm{~h}$. The beaker was subsequently removed from the water bath and the as-formed magnetic iron oxide particles were washed with water until the magnetic suspension reached neutral $\mathrm{pH}$. The as-obtained iron oxide was $\mathrm{Fe}_{3} \mathrm{O}_{4}$. With the aim to produce magnetic biochar, $1 \mathrm{~g}$ of biochar powder was thoroughly mixed in a small beaker with $2 \mathrm{~mL}$ of the magnetic suspension at constant temperature $(353 \mathrm{~K}$, water bath) for $6 \mathrm{~h}$. This mixture was dried completely at $333 \mathrm{~K}$ for $24 \mathrm{~h}$. In the process of mixing, the $\mathrm{Fe}_{3} \mathrm{O}_{4}$ was subsided on the surface of biochar or into the pore structure of biochar. ${ }^{24}$ Finally, the dried material was reground to obtain small particles. Furthermore, the experiment of iron leaching from $\mathrm{MBC}$ within $\mathrm{pH} 2$ to 11 was carried out to check the stability of MBC. ${ }^{18}$

\section{Biochar characterization}

The as-prepared BC and MBC samples were analyzed as follows: (1) the specific surface area was determined on a BrunauerEmmett-Teller surface area $\left(S_{\text {BET }}\right)$ analyzer (ASAP 2020, Micromeritics, USA); (2) the surface morphology and structure were examined by scanning electron microscopy (SEM, S250MK3, Cambridge UK Co., UK); (3) the high resolution structure of the materials were determined by transmission electron microscopy (TEM, JEM-2010, Japanese electronic optical CO., LTD); (4) the elemental analysis was carried out on an elemental analyzer (Vario EL, German Elementar Co., Germany); (5) the functional groups on the biochars before and after metal loading were determined by Fourier transform infrared spectroscopy (FTIR, Germany BRUKER spectrometer Co., Germany); (6) the phase composition was analyzed by X-ray diffraction (XRD, Empyrean, Netherlands); (7) the $\mathrm{pH}_{\mathrm{zpc}}$ was measured on a ZETASIZER 3000 HSA system (Zetasizer Nano, UN); (8) the binding energy of the $\mathrm{Pb}$ (II)- and U(VI)-loaded biochars on the surface and ca. $10 \mathrm{~nm}$ in deep were determined by X-ray photoelectron spectroscopy (XPS, Omicron Nanotechnology, Ltd.) and the Casa XPS program was used for the analysis of the spectra; and (9) the thermal stability of biochars was verified by thermogravimetric analysis (TGA, Discovery TGA 5500, TA instruments CO., USA).

\section{Batch experiments}

Batch mode adsorption studies were conducted to investigate the influence of some parameters used herein such as the biochar dosage $\left(0-1.0 \mathrm{~g} \mathrm{~L}^{-1}\right)$, the $\mathrm{pH}(2-11)$, the coexisting anion $\left(\mathrm{NO}_{3}{ }^{-}\right.$and $\mathrm{PO}_{4}{ }^{3-}, 0.001-0.1 \mathrm{~mol} \mathrm{~L}^{-1}$ ), the contact time (10 min$24 \mathrm{~h}$ ), the initial concentration (10-80 $\left.\mathrm{mg} \mathrm{L}^{-1}\right)$ of $\mathrm{Pb}(\mathrm{II})$ and $\mathrm{U}(\mathrm{VI})$, 
the reaction system temperature $(298,313$, and $328 \mathrm{~K})$, and the adsorption-desorption recycling time (1-5) during $\mathrm{Pb}$ (II) and $\mathrm{U}(\mathrm{vI})$ adsorption. All the batch experiments were performed with $10 \mathrm{~mL}$ polyethylene (PE) tubes. The mixed solutions of all batch experiments were shaken at $150 \mathrm{rpm}$ and $25{ }^{\circ} \mathrm{C}$ for $8 \mathrm{~h}$. A specific method was used for the adsorption-desorption recycling experiments. After adsorption of $\mathrm{Pb}(\mathrm{II})$ and $\mathrm{U}(\mathrm{VI})$, the $\mathrm{BC}$ and MBC samples were soaked in $0.01 \mathrm{M} \mathrm{HCl}$, shaken for $24 \mathrm{~h}$, and subsequently washed with water and alcohol. Finally, the as-obtained $\mathrm{BC}$ and $\mathrm{MBC}$ were dried at $348 \mathrm{~K}$ for further use. ${ }^{27}$ The suspension was filtered with a $0.45 \mu \mathrm{m}$ polysulfone filter membrane. The concentration of $\mathrm{Pb}$ (II) and $\mathrm{U}(\mathrm{VI})$ remaining in the supernatant solution was measured by inductively coupled plasma coupled with mass spectrometry (ICP-MS, Agilent 7500, USA). Each batch experiment involved three parallel samples, and a blank experiment was conducted following the same test procedure. The relative data error was generally within $5 \%$. The removal efficiency and the adsorbed amount of $\mathrm{Pb}$ (II) and $\mathrm{U}(\mathrm{VI})$ at equilibrium $\left(q_{\mathrm{e}}\left(\mathrm{mg} \mathrm{g}^{-1}\right)\right)$ were calculated using eqn (1) and (2), respectively: ${ }^{28}$

$$
\begin{gathered}
\text { Removal rate }=100 \% \times \frac{\left(C_{0}-C_{\mathrm{e}}\right)}{C_{0}} \\
q_{\mathrm{e}}=\left(C_{0}-C_{\mathrm{e}}\right) \times \frac{V}{m}
\end{gathered}
$$

where $C_{0}$ is the initial concentration of $\mathrm{Pb}(\mathrm{II})$ or $\mathrm{U}(\mathrm{vI})\left(\mathrm{mg} \mathrm{L}^{-1}\right)$, $C_{\mathrm{e}}$ represents the equilibrium concentration of $\mathrm{Pb}(\mathrm{II})$ or $\mathrm{U}(\mathrm{vI})$ $\left(\mathrm{mg} \mathrm{L}^{-1}\right), V$ is the volume of the suspension $(\mathrm{mL})$, and $m$ is the weight of $\mathrm{BC}$ and $\mathrm{MBC}(\mathrm{g})$.

With the aim to understand the mechanism governing the adsorption of $\mathrm{Pb}(\mathrm{II})$ and $\mathrm{U}(\mathrm{VI})$ over $\mathrm{BC}$ and $\mathrm{MBC}$, pseudo-firstorder and pseudo-second-order kinetic models were used to describe the adsorption kinetic data of $\mathrm{Pb}(\mathrm{II})$ and $\mathrm{U}(\mathrm{VI})$. The pseudo-first-order and pseudo-second-order models can be described by the following equations: ${ }^{2}$

$$
\begin{gathered}
q_{t}=q_{\mathrm{e}}\left[1-\exp \left(-K_{1} t\right)\right] \text { (Pseudo-first-order) } \\
q_{t}=q_{\mathrm{e}}-\frac{q_{\mathrm{e}}}{\left[K_{2}\left(q_{\mathrm{e}}\right) t+1\right]} \quad(\text { Pseudo-second-order })
\end{gathered}
$$

where $K_{1}$ is the rate constant of the pseudo-first-order adsorption model $\left(\mathrm{min}^{-1}\right), K_{2}$ is the rate constant of the pseudosecond-order adsorption model $\left(\mathrm{g} \mathrm{mg}^{-1} \mathrm{~min}^{-1}\right)$, and $q_{t}$ and $q_{\mathrm{e}}$ $\left(\mathrm{mg} \mathrm{g}^{-1}\right)$ are the amounts of metal ions adsorbed at a contact time $t(\mathrm{~h})$ and at equilibrium, respectively.

The Langmuir and Freundlich models were applied to simulate the adsorption isotherms. ${ }^{29}$ The equations for the Langmuir and Freundlich models are described by the following equations:

$$
\begin{aligned}
& q_{\mathrm{e}}=\frac{Q_{\max } K_{\mathrm{L}} C_{\mathrm{e}}}{1+K_{\mathrm{L}} C_{\mathrm{e}}} \quad \text { (Langmuir) } \\
& q_{\mathrm{e}}=K_{\mathrm{F}} C_{\mathrm{e}}^{1 / n_{\mathrm{F}}} \text { (Freundlich) }
\end{aligned}
$$

where $q_{\mathrm{e}}$ is the equilibrium adsorption capacity of $\mathrm{Pb}$ (II) and $\mathrm{U}(\mathrm{vI})$ on $\mathrm{BC}$ and $\mathrm{MBC}\left(\mathrm{mg} \mathrm{g}^{-1}\right), Q_{\max }$ is the maximum adsorption capacity $\left(\mathrm{mg} \mathrm{g}^{-1}\right), K_{\mathrm{L}}$ is the Langmuir adsorption characteristic constant $\left(\mathrm{L} \mathrm{mg}^{-1}\right)$ related to the enthalpy of the adsorption process, $C_{\mathrm{e}}$ is the adsorption equilibrium concentration of $\mathrm{Pb}$ (II) and $\mathrm{U}(\mathrm{vI})$ after equilibrium $\left(\mathrm{mg} \mathrm{L}^{-1}\right), K_{\mathrm{F}}$ is the Freundlich equilibrium constant $\left(\mathrm{mg} \mathrm{g}^{-1}\left(\mathrm{mg} \mathrm{L}^{-1}\right)^{-1 / n_{\mathrm{F}}}\right)$, and $n_{\mathrm{F}}$ is dimensionless exponent of the Freundlich equation which varies with the degree of heterogeneity of adsorbing sites.

Moreover, thermodynamic parameters such as the Gibbs free energy $\left(\Delta G^{0}\right)$, enthalpy $\left(\Delta H^{0}\right)$, and entropy $\left(\Delta S^{0}\right)$ changes were used to evaluate the feasibility and nature of the adsorption reaction. They were calculated using the following equations:

$$
\begin{gathered}
\Delta G^{0}=-R T \ln K \\
\Delta G^{0}=\Delta H^{0}-T \Delta S^{0} \\
\ln K=\frac{\Delta S^{0}}{R}-\frac{\Delta H^{0}}{R T}
\end{gathered}
$$

where $R$ is the gas constant $\left(8.314 \mathrm{~J} \mathrm{~mol}^{-1} \mathrm{~K}^{-1}\right), T$ is the absolute temperature (K), and $K$ is an equilibrium constant obtained by multiplying the Langmuir constants $Q_{\max }$ and $K_{\mathrm{L}}$.

\section{Results and discussion}

\section{Characteristics of the biochars}

Some selected physicochemical properties of BC and MBC are listed in Table 1. MBC $\left(109 \mathrm{~m}^{2} \mathrm{~g}^{-1}\right.$ and $\left.0.05 \mathrm{~cm}^{3} \mathrm{~g}^{-1}\right)$ showed higher BET surface area and micropore volume as compared to BC $\left(52.1 \mathrm{~m}^{2} \mathrm{~g}^{-1}\right.$ and $\left.0.02 \mathrm{~cm}^{3} \mathrm{~g}^{-1}\right)$, probably as a result of the addition of $\mathrm{Fe}_{x} \mathrm{O}_{y}$, in line with the results reported by Mohan. ${ }^{30}$ $\mathrm{BC}$ and $\mathrm{MBC}$ were both weakly alkaline (average $\mathrm{pH}$ values of 9.08 and 8.55, respectively). BC and MBC both showed low $\mathrm{pH}_{\mathrm{pzc}}$ values $(<5.0)$, thereby revealing high acidic characteristics and a strong buffer capacity under basic environments. The higher $\mathrm{pH}_{\mathrm{pzc}}$ value of $\mathrm{BC}$ (4.32) might be ascribed to the presence of a higher amount of basic functional groups in this

Table 1 Chemical and physical properties of the biochar samples ${ }^{a}$

\begin{tabular}{lll}
\hline & \multicolumn{2}{l}{ Biochars } \\
\cline { 2 - 3 } Characteristics units & BC & MBC \\
\hline BET surface area, $\mathrm{m}^{2} \mathrm{~g}^{-1}$ & 52.1 & 109 \\
$V_{\mathrm{p}}, \mathrm{cm}^{3} \mathrm{~g}^{-1}$ & 0.02 & 0.05 \\
$\mathrm{pH}$ & 9.08 & 8.55 \\
$\mathrm{pH}$ & 4.32 & 3.71 \\
$\mathrm{C}, \%$ & 56.3 & 40.7 \\
$\mathrm{H}, \%$ & 2.05 & 1.65 \\
$\mathrm{O}, \%$ & 35.9 & 21.4 \\
$\mathrm{~N}, \%$ & 0.71 & 0.47 \\
$\mathrm{~S}, \%$ & 0.16 & 0.12 \\
$\mathrm{Fe}, \%$ & - & 8.49 \\
$\mathrm{O} / \mathrm{C}$ ratio & 0.48 & 0.39 \\
$\mathrm{H} / \mathrm{C}$ ratio & 0.44 & 0.49
\end{tabular}

${ }^{a}$ BC: biochar; MBC: magnetic biochar; $S_{\mathrm{BET}}$ : surface area; $V_{\mathrm{p}}$ : micropore volume. 
biochar. ${ }^{31}$ Moreover, the magnetite surface coverage is likely responsible for the lower $\mathrm{pH}_{\mathrm{pzc}}$ of $\mathrm{MBC}(3.71) .{ }^{32}$ Iron ions were successfully adhered to BC, and the content in MBC was $8.49 \%$. The oxygen content and the $\mathrm{O} / \mathrm{C}$ ratio of $\mathrm{BC}$ were significantly higher than those of MBC. Thus, the former material was more hydrophilic because of the presence of a higher amount of basic functional groups. ${ }^{30}$

The structure and chemical composition of $\mathrm{BC}$ and $\mathrm{MBC}$ are shown in Fig. 1. As shown in the SEM micrographs (Fig. 1a and b), the magnetic modification process resulted in a biochar having a rough surface and abundant of micro-spheres and mineral particles, which can provide abundant adsorption points, further enhancing the adsorption capacity of the biochar. ${ }^{24}$ According to the XRD analysis, these micro-spheres and mineral particles in $\mathrm{MBC}$ might be formed by $\mathrm{Fe}_{3} \mathrm{O}_{4}$ (Fig. 1c). The five intense characteristic peaks detected at 2 theta $=30.5$, $33.0,41.7,52.6$, and $57.1^{\circ}$ corresponded to the primary diffraction of the (220), (310), (400), (422), and (511) facets of a cubic spinel crystal $\mathrm{Fe}_{3} \mathrm{O}_{4}$ phase (JCPDS no. 19-692). ${ }^{25}$ To further analyze the surface chemical composition of the biochar samples, the XPS spectra (full scan 0-1200 eV) of BC and MBC were determined (Fig. 1d). The photoelectron lines at ca. 284, 400, and $533 \mathrm{eV}$ corresponded to the $\mathrm{C} 1 \mathrm{~s}, \mathrm{~N} 1 \mathrm{~s}$, and $\mathrm{O} 1 \mathrm{~s}$ signals of BC and MBC. Lines at binding energies of 710-721 eV corresponding to $\mathrm{Fe} 2 \mathrm{p}_{3 / 2}$ were detected for $\mathrm{MBC}$ and assigned to $\mathrm{Fe}^{3+}$ species, in line with the results reported by Trakal et al. ${ }^{23}$
The TEM images (Fig. 2a and b) of BC and MBC shown that a number of black spots were visible in Fig. 2b, which confirmed agglomerated, irregular, non-uniform, and spherical $\mathrm{Fe}_{3} \mathrm{O}_{4}$ particles were successfully adhered to BC via the hydrothermal synthesis method. ${ }^{33}$ Both BC and MBC showed no difference in their thermal stability (Fig. 2c and d), and they all experienced a three-step weight loss in the TG curve. ${ }^{34}$ During the first stage, a $\sim 2.5 \%$ weight loss occurred before $150{ }^{\circ} \mathrm{C}$, which was due to the dehydration of physically adsorbed water molecules. Then a $\sim 7 \%$ weight loss occurred between 150 and $600{ }^{\circ} \mathrm{C}$ which was related with decomposition of hemicellulose, cellulose and lignin. A third stage, a 4-5\% weight loss occurred within 600 and $800{ }^{\circ} \mathrm{C}$, was probably due to the breakage of $\mathrm{CO}_{3}{ }^{2-}$.

\section{Effect of the biochar loading}

The adsorbent dosage has been regarded as a crucial factor affecting the removal of contaminants. ${ }^{35}$ The influence of the biochar dosage on the $\mathrm{Pb}(\mathrm{II})$ and $\mathrm{U}(\mathrm{VI})$ adsorption capacities is shown in Fig. 3. The $\mathrm{Pb}(\mathrm{II})$ and $\mathrm{U}(\mathrm{VI})$ removal rates increased with the biochar dosage. As reported by Trakal et $a .^{23}$ and Samsuri et al., ${ }^{36}$ MBC showed higher removal rates than $\mathrm{BC}$, especially for $\mathrm{U}(\mathrm{VI})$. Thus, while the removal rate of $\mathrm{Pb}(\mathrm{II})$ in solution was similar for both biochar samples and increased linearly with the biochar loading (48.1 vs. $50.8 \%$ at $0.02 \mathrm{~g} \mathrm{~L}^{-1}$ and 90.9 vs. $91.7 \%$ at $1.00 \mathrm{~g} \mathrm{~L}^{-1}$ for BC and $\mathrm{MBC}$, respectively, Fig. 3a), U(vI) in solution was more rapidly removed by $\mathrm{MBC}$,
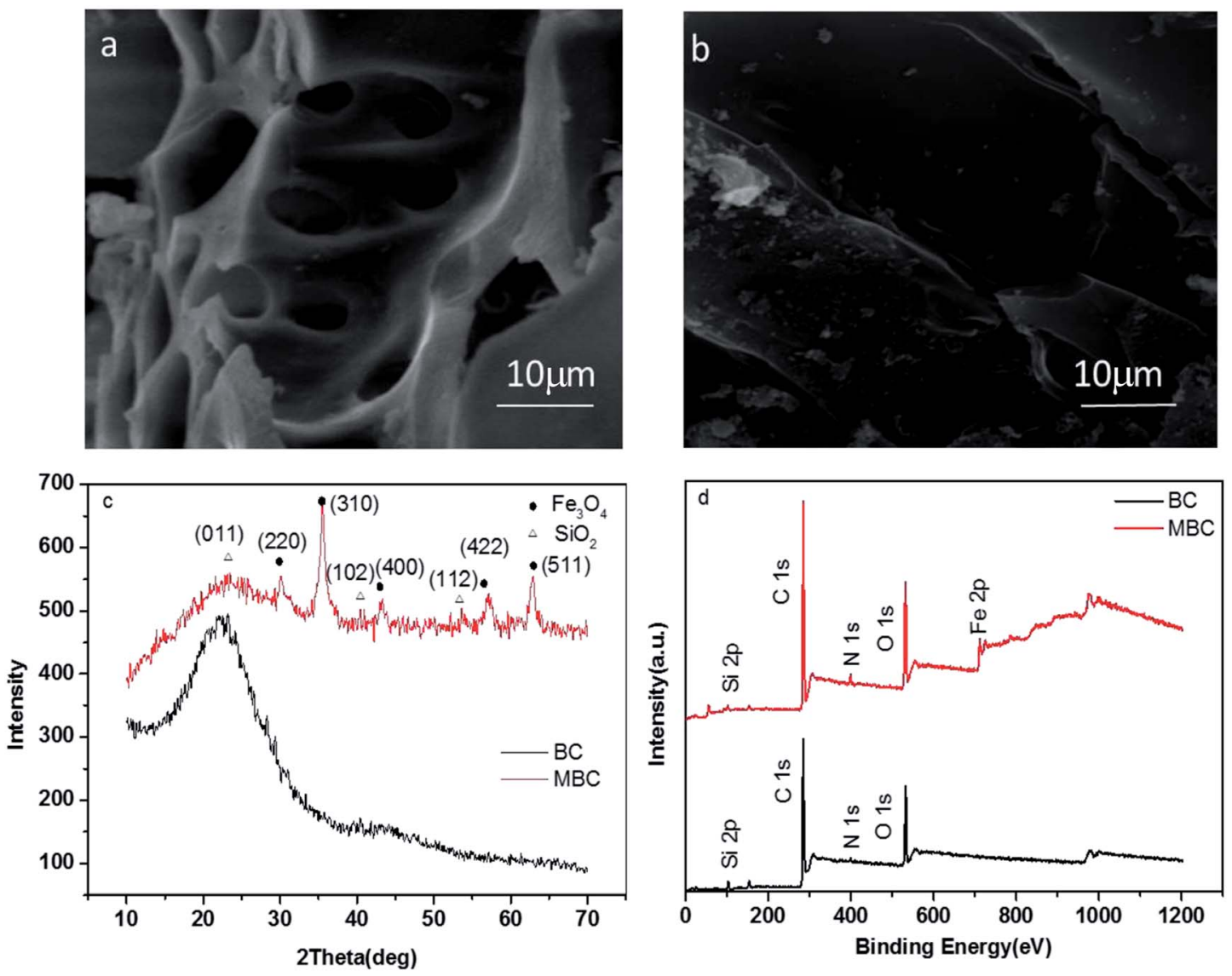

Fig. 1 SEM images (a and b), XRD patterns (c), and XPS spectra (d) of BC and MBC, respectively. 

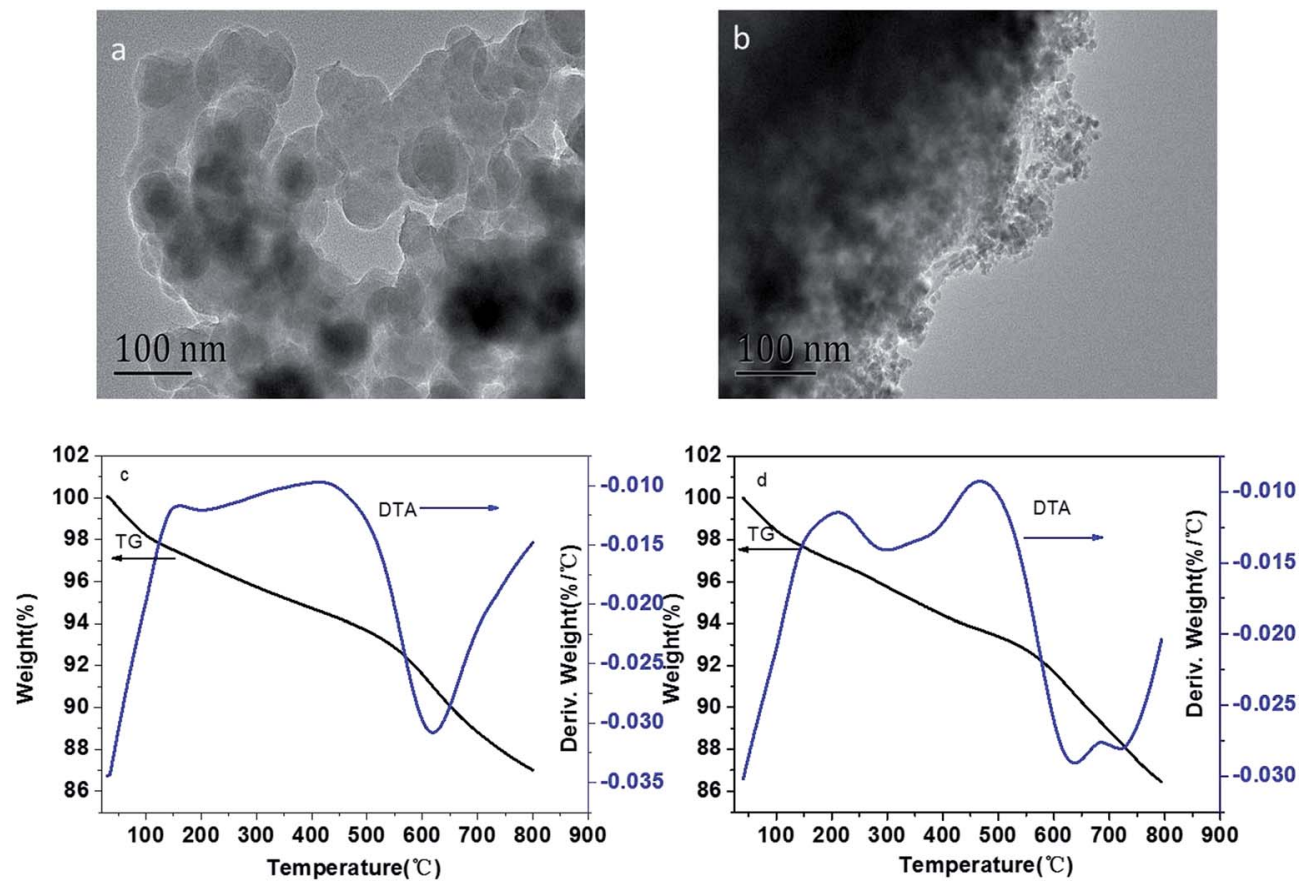

Fig. 2 TEM images and TGA curves of $B C$ ( $a$ and $c$ ) and MBC ( $b$ and d), respectively.

and the removal rate increased nonlinearly with the biochar loading (5.5 vs. $13.0 \%$ at $0.02 \mathrm{~g} \mathrm{~L}^{-1}$ and 90.2 vs. $96.8 \%$ at $1.00 \mathrm{~g}$ $\mathrm{L}^{-1}$ for $\mathrm{BC}$ and $\mathrm{MBC}$, respectively, Fig. 3b). While increasing the biochar loading is advantageous in that it provides more active sites for adsorption, excessive dosages can lead to adsorbent aggregation issues which reduce the number of binding sites and promote biochar-metal ions electrostatic repulsion. ${ }^{37}$ As shown in Fig. 3, BC and MBC both showed high $\mathrm{Pb}(\mathrm{II})$ and $\mathrm{U}(\mathrm{VI})$ removal rates. From the economic and environmental viewpoints, $0.4 \mathrm{~g} \mathrm{~L}^{-1}$ was selected herein as the optimum biochar loading.
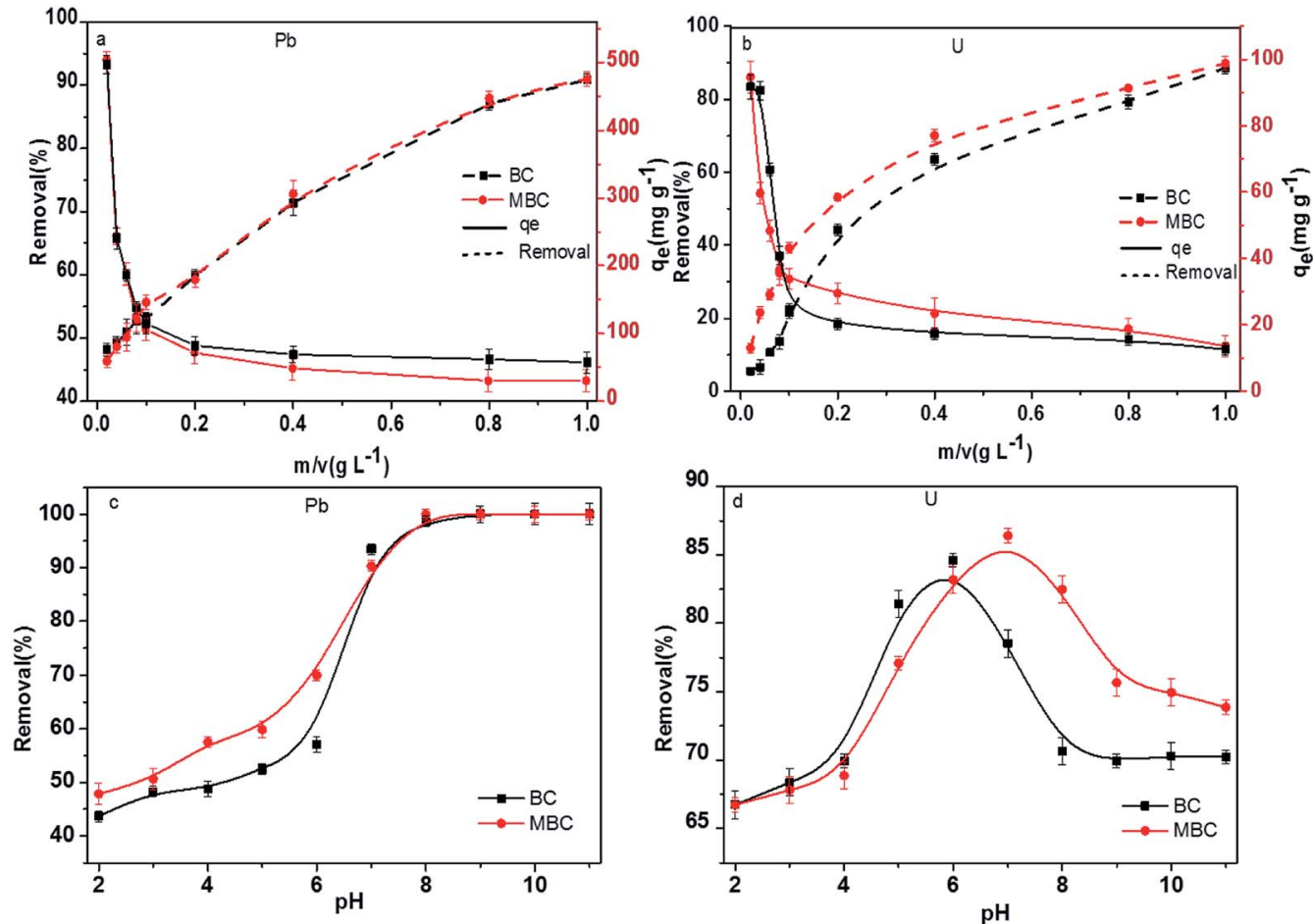

Fig. 3 Removal of $\mathrm{Pb}(॥)(\mathrm{a})$ and $\mathrm{U}(\mathrm{VI})(\mathrm{b})$ in solution over $\mathrm{BC}$ and $\mathrm{MBC}$ as a function of the biochar dosage. Removal of $\mathrm{Pb}(\mathrm{II})(\mathrm{c})$ and $\mathrm{U}(\mathrm{VI})$ (d) in solution over $\mathrm{BC}$ and $\mathrm{MBC}$ as a function of the $\mathrm{pH}$. 

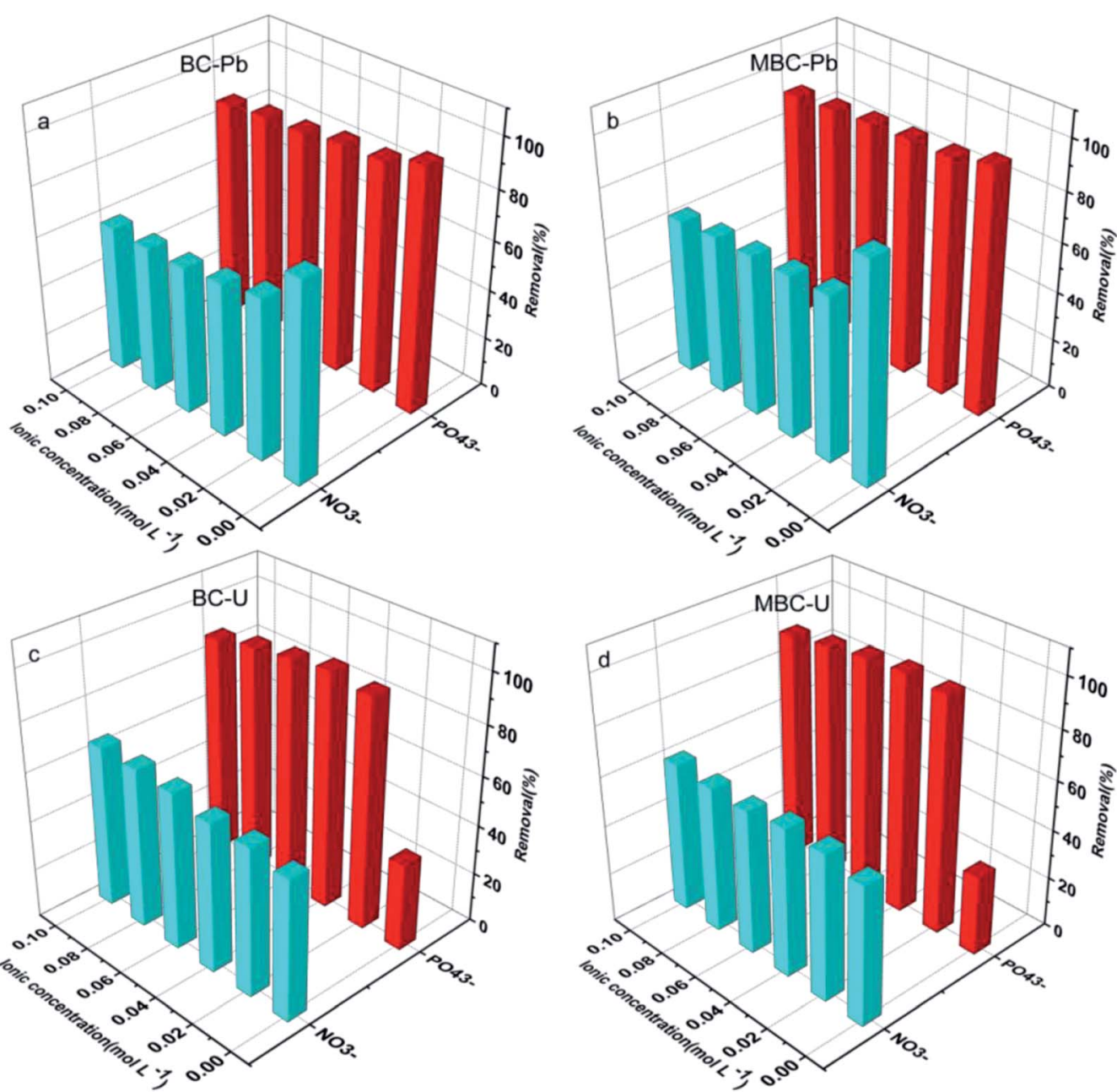

Fig. 4 Effect of the ionic concentration of $\mathrm{NO}_{3}{ }^{-}$and $\mathrm{PO}_{4}{ }^{3-}$ on the adsorption of $\mathrm{Pb}(\mathrm{II})(\mathrm{a}$ and $\mathrm{b})$ and $\mathrm{U}(\mathrm{VI})$ ( $\mathrm{c}$ and d) on $\mathrm{BC}$ and $\mathrm{MBC}$, respectively.

\section{Effect of the pH}

The initial $\mathrm{pH}$ of the solution can significantly influence the adsorption of metals over biochars by altering the surface charge and the nature of the functional groups on the adsorbent, the metal ion speciation, or its solubility. ${ }^{30}$ Thus, the effect of the initial $\mathrm{pH}$ on the removal of $\mathrm{Pb}(\mathrm{II})$ and $\mathrm{U}(\mathrm{vI})$ over $\mathrm{BC}$ and MBC was analyzed (Fig. $3 \mathrm{c}$ and d). The adsorption of $\mathrm{Pb}(\mathrm{II})$ and $\mathrm{U}(\mathrm{vI})$ were noticeably affected by the $\mathrm{pH}$ of the solution. The removal efficiency of $\mathrm{Pb}$ (II) showed a S-shaped curve with the $\mathrm{pH}, \mathrm{U}(\mathrm{vI})$ showed an inverted U-shaped trend. At low $\mathrm{pH}$ values (2-5), $\mathrm{Pb}$ (II) removal was inhibited because $\mathrm{H}^{+}$competed with $\mathrm{Pb}(\mathrm{II})$ for the adsorption sites. At low $\mathrm{pH}$ values, both $\mathrm{BC}\left(\mathrm{pH}_{\mathrm{zpc}}\right.$ $=4.32)$ and $\mathrm{MBC}\left(\mathrm{pH}_{\mathrm{zpc}}=3.71\right)$ showed positive charges, thereby hindering the contact between the $\mathrm{Pb}$ (II) ions and the biochar surface via high electrostatic repelling forces. At higher $\mathrm{pH}$ values $(\mathrm{pH}>5)$, some $\mathrm{Pb}(\mathrm{II})$ hydrolysis products such as $\mathrm{Pb}(\mathrm{OH})_{2}$ were formed, and both adsorption and precipitation processes accounted for the removal of $\mathrm{Pb}(\mathrm{II})$. However, at $\mathrm{pH}$ values lower than $8, \mathrm{~Pb}$ was mainly as $\mathrm{Pb}^{2+}$ in solution, and electrostatic attraction between $\mathrm{Pb}$ and biochar was the main adsorption driving force. At higher $\mathrm{pH}$ values (8-11), protonation-deprotonation processes of carboxyl and hydroxyl groups on the biochar prevailed, ${ }^{38}$ thereby inhibiting the adsorption of $\mathrm{Pb}(\mathrm{II})$.

In the case of $\mathrm{U}(\mathrm{vI})$, the removal efficiency over $\mathrm{BC}$ and $\mathrm{MBC}$ first increased slowly with the $\mathrm{pH}(2-4)$, after which a rapid increase was observed ( $\mathrm{pH}=4-6$ for $\mathrm{BC}$ and $\mathrm{pH}=4-7$ for $\mathrm{MBC})$. At higher $\mathrm{pH}$ values $(\mathrm{pH}=6-8$ for $\mathrm{BC}$ and $\mathrm{pH}=7-9$ for $\mathrm{MBC})$ the removal efficiency of $\mathrm{U}(\mathrm{vI})$ dropped significantly, and slowly decreased for $\mathrm{pH}$ values exceeding 8 (BC) and 9 (MBC). The low adsorption efficiency of $\mathrm{U}(\mathrm{vI})$ at low $\mathrm{pH}$ values (2-4) could be attributed to the competition of $\mathrm{H}^{+}$with $\mathrm{U}(\mathrm{vI})$ for the adsorptive active sites and the higher positive charge of the biochar. At $\mathrm{pH}<\mathrm{pH}_{\mathrm{pzc}}$, the surface charge of the both biochars are positive because of the protonation reaction. Thus, the positive $\mathrm{U}(\mathrm{vI})$ ions are adsorbed with difficulty on the positively charged surface of the $\mathrm{BC}$ and $\mathrm{MBC}$ because of the electrostatic repulsion. ${ }^{39}$ At $\mathrm{pH}$ values above 6 (BC) and 7 (MBC), hydroxide $\mathrm{U}(\mathrm{vI})$ species such as $\mathrm{UO}_{2}(\mathrm{OH})^{+}, \quad\left(\mathrm{UO}_{2}\right)_{2}(\mathrm{OH})_{2}$, and $\left(\mathrm{UO}_{2}\right)_{3}(\mathrm{OH})_{5}{ }^{2+}$ were formed, thereby decreasing the removal ability of the biochar. ${ }^{39}$ The presence of $\mathrm{Fe}^{3+}$ on $\mathrm{MBC}$ might alter the interaction of $\mathrm{OH}^{-}$with $\mathrm{U}(\mathrm{vI})$, thereby hindering the precipitation of hydroxides and reaching maximum removal 

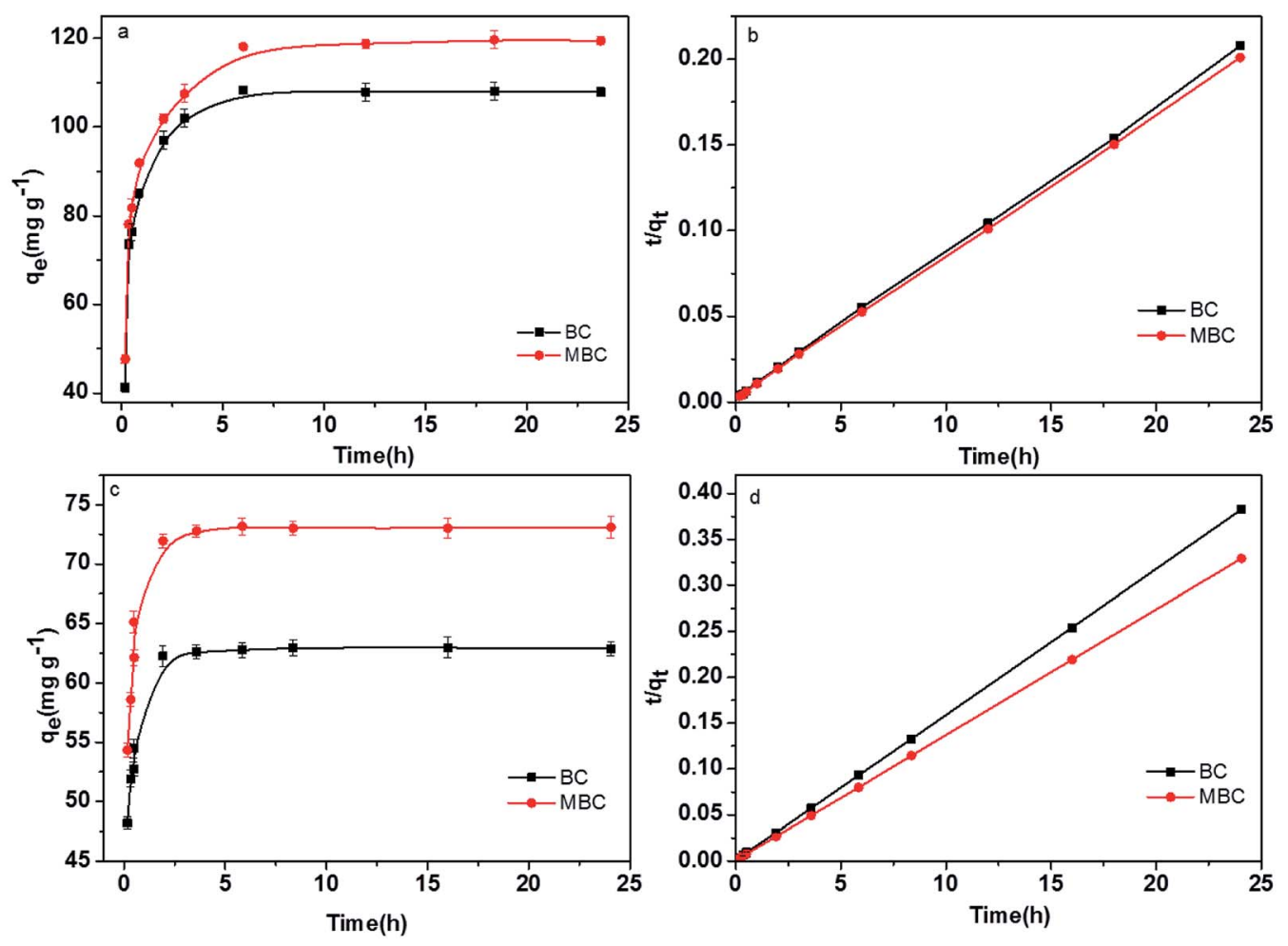

Fig. 5 Effect of the contact time on the adsorption of $\mathrm{Pb}(\mathrm{I})$ and $\mathrm{U}(\mathrm{VI})$ over $\mathrm{BC}$ and $\mathrm{MBC}$. (a and c) Pseudo-first-order model for the adsorption of $\mathrm{Pb}(\|)$ and $\mathrm{U}(\mathrm{VI})$; (b and d) pseudo-second-order model for the adsorption of $\mathrm{Pb}(\|)$ and $\mathrm{U}(\mathrm{VI})$, respectively.

rates at higher $\mathrm{pH}$ values ( 7 vs. 6) as compared to $\mathrm{BC}$. $\mathrm{BC}$ and $\mathrm{MBC}$ both showed high removal rates for $\mathrm{Pb}(\mathrm{II})$ and $\mathrm{U}(\mathrm{VI})$ at a $\mathrm{pH}$ of 7 . Thus, this value was used for further $\mathrm{Pb}(\mathrm{II})$ and $\mathrm{U}(\mathrm{vI})$ adsorption experiments on $\mathrm{BC}$ and MBC.

\section{Effect of the coexisting anions}

Considering the complexity of water bodies (especially eutrophic waters), some coexisting anions such as $\mathrm{NO}_{3}{ }^{-}$and $\mathrm{PO}_{4}{ }^{3-}$ might affect the uptake capacity of biochar towards the metal. ${ }^{24}$ The presence of $\mathrm{NO}_{3}{ }^{-}$and $\mathrm{PO}_{4}{ }^{3-}$ significantly reduced the adsorption efficiency of $\mathrm{Pb}$ (II) on $\mathrm{BC}$ and $\mathrm{MBC}$, whereas the removal rate of $\mathrm{U}(\mathrm{vI})$ noticeably increased with the concentration of $\mathrm{PO}_{4}{ }^{3-}$ in solution for both biochar samples (Fig. 4). In the case of $\mathrm{Pb}(\mathrm{II})$, the adsorption efficiency rapidly decreased with the concentration of $\mathrm{NO}_{3}{ }^{-}$and $\mathrm{PO}_{4}{ }^{3-}$ increasing from 0 to $0.02 \mathrm{~mol} \mathrm{~L}^{-1}$ and moderately dropped at higher concentrations of coexisting anions on both biochars. While the adsorption efficiency of $\mathrm{U}(\mathrm{vI})$ slightly increased with the concentration of
$\mathrm{NO}_{3}{ }^{-}$, a different trend was observed for $\mathrm{PO}_{4}{ }^{3-}$. Thus, the adsorption efficiency of $\mathrm{U}(\mathrm{vI})$ first increased rapidly with the concentration of $\mathrm{PO}_{4}{ }^{3-}\left(0-0.02 \mathrm{~mol} \mathrm{~L}^{-1}\right)$ and moderately increased thereafter before reaching equilibrium. This phenomenon could be attributed to these reasons: (1) outer surface complexes were formed by interaction of $\mathrm{Pb}$ (II) and biochar, with electrostatic attraction being the main adsorption mechanism of $\mathrm{Pb}$ (II) over $\mathrm{BC}$ and MBC. As a result, the presence of $\mathrm{NO}_{3}{ }^{-}$and $\mathrm{PO}_{4}{ }^{3-}$ in solution altered the electrostatic interaction between the surface charges of biochar and the $\mathrm{Pb}$ (II) ions in solution while also competing with them for the surface adsorption sites. (2) Inner surface complexes were formed by interaction of $\mathrm{U}(\mathrm{vI})$ and biochar, with complex surface coordination and precipitation being the main mechanisms governing the adsorption of $\mathrm{U}(\mathrm{vI})$ over $\mathrm{BC}$ and $\mathrm{MBC}$. Thus, the dissolution $\mathrm{PO}_{4}{ }^{3-}$ and $\mathrm{UO}_{2}{ }^{2+}$ contributed to form coordination and oversaturate conditions; ${ }^{40}(3)$ the ionic strength of $\mathrm{NO}_{3}{ }^{-}$ and $\mathrm{PO}_{4}{ }^{3-}$ influenced the activity coefficient of $\mathrm{Pb}(\mathrm{II})$ to a higher

Table 2 Adsorption kinetics parameters for the adsorption of $\mathrm{Pb}(\mathrm{I})$ and $\mathrm{U}(\mathrm{VI})$ on $\mathrm{BC}$ and $\mathrm{MBC}$

\begin{tabular}{|c|c|c|c|c|c|c|c|}
\hline Metals & Biochars & $q_{\mathrm{e}}\left(\mathrm{mg} \mathrm{g}^{-1}\right)$ & $K_{1}\left(\min ^{-1}\right)$ & $R^{2}$ & $q_{\mathrm{e}}\left(\mathrm{mg} \mathrm{L}^{-1}\right)$ & $K_{2}\left(\mathrm{~g} \mathrm{mg}^{-1} \min ^{-1}\right)$ & $R^{2}$ \\
\hline $\mathrm{Pb}$ (II) & $\mathrm{MBC}$ & 112 & 0.19 & 0.898 & 137 & 0.04 & 0.902 \\
\hline \multirow[t]{2}{*}{$\mathrm{U}(\mathrm{vI})$} & $\mathrm{BC}$ & 61.0 & 0.27 & 0.938 & 90.1 & 0.07 & 0.999 \\
\hline & $\mathrm{MBC}$ & 71.3 & 0.16 & 0.967 & 77.7 & 0.05 & 0.999 \\
\hline
\end{tabular}



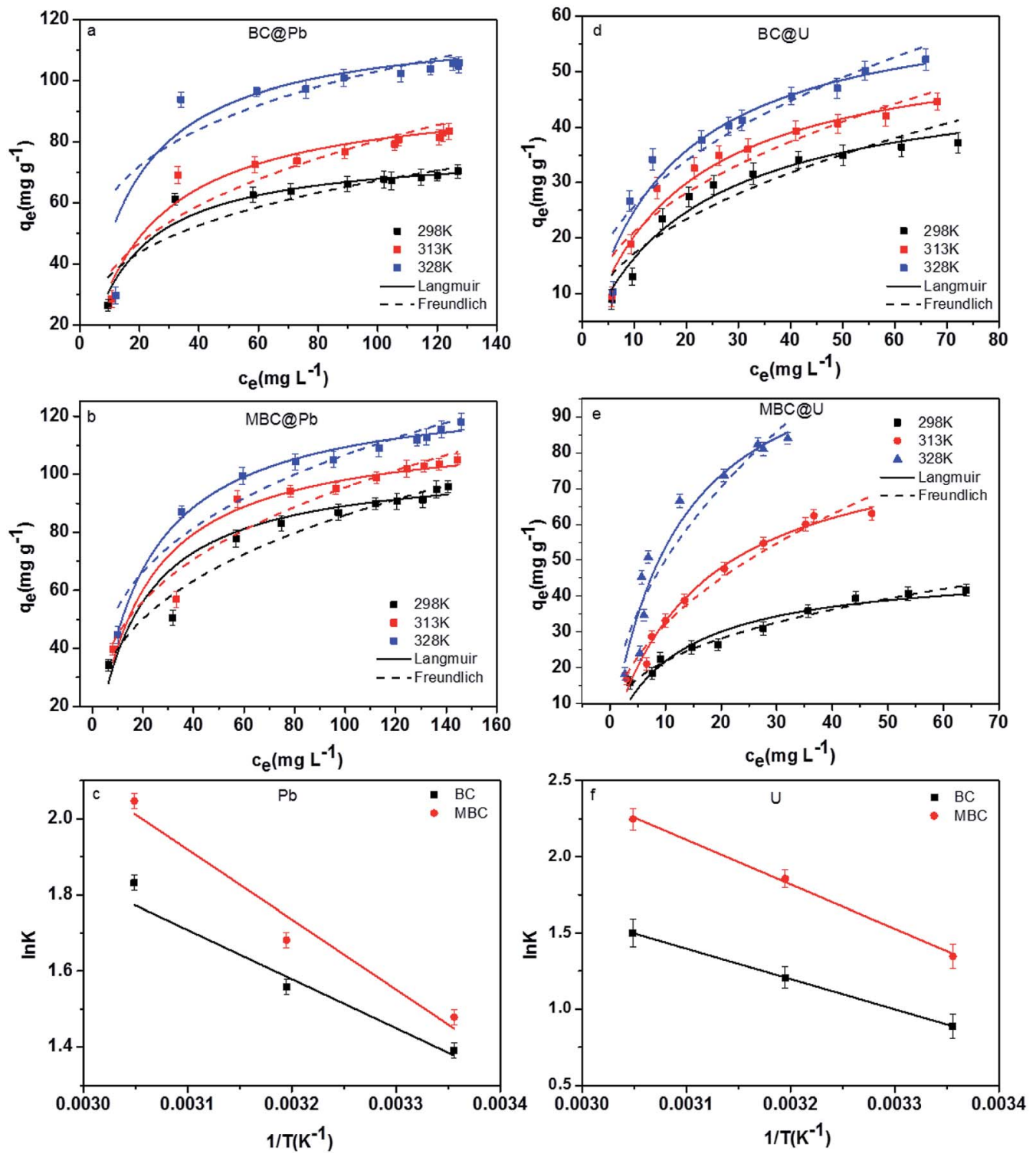

Fig. 6 Adsorption isotherms and linear plot of $\ln K$ vs. $1 / T$ for $\mathrm{Pb}(\mathrm{II})(\mathrm{a}-\mathrm{C})$ and for $\mathrm{U}(\mathrm{VI})(\mathrm{d}-\mathrm{f})$ on $\mathrm{BC}$ and $\mathrm{MBC}$, respectively.

extent as compared to $\mathrm{U}(\mathrm{vI})$, thereby limiting the transfer of $\mathrm{Pb}$ (II) on the biochar surface. The optimum anion strengths of $\mathrm{NO}_{3}{ }^{-}$and $\mathrm{PO}_{4}{ }^{3-}$ were $0.01 \mathrm{~mol} \mathrm{~L}^{-1}$ for $\mathrm{Pb}(\mathrm{II})$ and $0.04 \mathrm{~mol} \mathrm{~L}^{-1}$ for $\mathrm{U}(\mathrm{vI})$, respectively.

\section{Adsorption kinetics}

The effect of contact time on the adsorption of $\mathrm{Pb}(\mathrm{II})$ and $\mathrm{U}(\mathrm{VI})$ on BC and MBC were depicted in Fig. 5. The pseudo-secondorder model showed better $R^{2}$ values than the pseudo-firstorder model (Table 2). Thus, the pseudo-second-order model better described the adsorption of $\mathrm{Pb}(\mathrm{II})$ and $\mathrm{U}(\mathrm{VI})$ on $\mathrm{BC}$ and MBC. This result revealed that, in addition to physical adsorption, chemical interactions were also involved in the adsorption of $\mathrm{Pb}$ (II) and $\mathrm{U}$ (VI). ${ }^{\mathbf{4 1 , 4 2}} \mathrm{Pb}$ (II) showed higher adsorption capacities and rates on $\mathrm{BC}$ and $\mathrm{MBC}$ as compared to $\mathrm{U}(\mathrm{vI})$. Additionally, the adsorption rate of $\mathrm{Pb}$ (II) on $\mathrm{BC}$ was higher than that on $\mathrm{MBC}$, thereby revealing that $\mathrm{Pb}$ (II) was physically adsorbed on the biochar, while $\mathrm{U}(\mathrm{vI})$ was preferably adsorbed via chemisorption processes on MBC owing to the higher number of functional groups of this material. ${ }^{\mathbf{4 0}}$

\section{Adsorption isotherms and thermodynamic characteristics}

Fig. 6 shows the adsorption isotherms and the thermodynamic characteristics of the adsorption of $\mathrm{Pb}(\mathrm{II})$ and $\mathrm{U}(\mathrm{VI})$ on $\mathrm{BC}$ and MBC under three different temperatures (i.e., 298, 313, and 328 $\mathrm{K})$. The corresponding parameters for the Langmuir and Freundlich models are listed in Table 3 . The coefficient correlation $\left(R^{2}\right)$ revealed that the Langmuir model provided a better fit to the adsorption of $\mathrm{Pb}$ (II) and $\mathrm{U}(\mathrm{VI})$ on $\mathrm{BC}$ and $\mathrm{MBC}$ as compared to the Freundlich model $\left(R^{2}=0.87-0.99\right.$ vs. 0.730.96). This result further confirmed that $\mathrm{Pb}(\mathrm{II})$ and $\mathrm{U}(\mathrm{VI})$ were adsorbed on the biochars forming a monolayer. ${ }^{27}$ The 
Table 3 Parameters for the adsorption isotherm models and values of some thermodynamic parameters for the adsorption of $\mathrm{Pb}(\mathrm{I})$ and $\mathrm{U}(\mathrm{VI})$ on $\mathrm{BC}$ and $\mathrm{MBC}$

\begin{tabular}{|c|c|c|c|c|c|c|c|c|c|c|c|}
\hline Metals & Biochars & $T$ & $Q_{\max }\left(\mathrm{mg} \mathrm{g}^{-1}\right)$ & $K_{\mathrm{L}}\left(\mathrm{L} \mathrm{mg}^{-1}\right)$ & $R^{2}$ & $K_{\mathrm{F}}$ & $n$ & $R^{2}$ & $\begin{array}{l}\Delta G^{0} \\
\left(\mathrm{~kJ} \mathrm{~mol}{ }^{-1}\right)\end{array}$ & $\begin{array}{l}\Delta S^{0} \\
\left(\mathrm{~J} \mathrm{~mol}^{-1}\right)\end{array}$ & $\begin{array}{l}\Delta H^{0} \\
\left(\mathrm{~kJ} \mathrm{~mol}^{-1}\right)\end{array}$ \\
\hline \multirow[t]{4}{*}{$\mathrm{Pb}(\mathrm{II})$} & \multirow[t]{3}{*}{$\mathrm{BC}$} & $298 \mathrm{~K}$ & 77.5 & 0.07 & 0.941 & 17.3 & 0.26 & 0.813 & -4.19 & \multirow[t]{3}{*}{51.3} & \multirow[t]{3}{*}{11.9} \\
\hline & & $313 \mathrm{~K}$ & 95.0 & 0.05 & 0.943 & 19.8 & 0.30 & 0.842 & -4.05 & & \\
\hline & & $328 \mathrm{~K}$ & 125 & 0.05 & 0.867 & 24.6 & 0.31 & 0.726 & -5.00 & & \\
\hline & MBC & $328 \mathrm{~K}$ & 129 & 0.06 & 0.990 & 32.8 & 0.26 & 0.951 & -5.58 & 63.3 & 15.3 \\
\hline \multirow[t]{5}{*}{$\mathrm{U}(\mathrm{vI})$} & \multirow[t]{3}{*}{$\mathrm{BC}$} & $298 \mathrm{~K}$ & 48.6 & 0.05 & 0.961 & 7.64 & 0.39 & 0.953 & -2.20 & \multirow[t]{3}{*}{63.0} & \multirow[t]{3}{*}{16.6} \\
\hline & & $313 \mathrm{~K}$ & 55.8 & 0.06 & 0.969 & 9.47 & 0.38 & 0.953 & -3.14 & & \\
\hline & & $328 \mathrm{~K}$ & 64.0 & 0.07 & 0.930 & 11.6 & 0.37 & 0.903 & -4.09 & & \\
\hline & \multirow[t]{2}{*}{ MBC } & $298 \mathrm{~K}$ & 53.2 & 0.08 & 0.931 & 9.58 & 0.36 & 0.981 & -3.34 & \multirow[t]{2}{*}{93.3} & \multirow[t]{2}{*}{24.4} \\
\hline & & $313 \mathrm{~K}$ & 87.4 & 0.06 & 0.984 & 10.7 & 0.48 & 0.970 & -4.31 & & \\
\hline
\end{tabular}

maximum adsorption capacities of $\mathrm{Pb}(\mathrm{II})$ and $\mathrm{U}(\mathrm{vI})$ on $\mathrm{BC}$ and MBC dictated by the Langmuir model at $298 \mathrm{~K}$ were 77.5 and $110 \mathrm{mg} \mathrm{g}^{-1}$ for $\mathrm{Pb}(\mathrm{II})$ and 48.6 and $53.2 \mathrm{mg} \mathrm{g}^{-1}$ for $\mathrm{U}(\mathrm{VI})$, respectively. The adsorption capacity of $\mathrm{Pb}(\mathrm{II})$ had a more increase than that of $\mathrm{U}(\mathrm{vI})$ after biochar magnetic modification. The $\mathrm{Pb}$ (II) removal potential from aqueous solutions by $\mathrm{BC}$ $\left(77.5 \mathrm{mg} \mathrm{g}^{-1}\right)$ and MBC $\left(110 \mathrm{mg} \mathrm{g}^{-1}\right)$ was significantly higher than other modified biochars (Table 4), such as those of oak wood-(10.1 mg g $\left.{ }^{-1}\right),{ }^{43}$ oak bark-(30.2 $\left.\mathrm{mg} \mathrm{g}^{-1}\right),{ }^{30}$ bamboo$\left(25.1 \mathrm{mg} \mathrm{g}^{-1}\right),{ }^{44}$ pine bark-(25.3 $\left.\mathrm{mg} \mathrm{g}^{-1}\right),{ }^{45}$ romchar-(17.7 mg $\left.\mathrm{g}^{-1}\right)$ and oxford $\left(32.2 \mathrm{mg} \mathrm{g}^{-1}\right)$ derived biochars ${ }^{46}$ and close to those of sewage- $\left(99.8 \mathrm{mg} \mathrm{g}^{-1}\right)$ derived biochars. ${ }^{47}$ For U(vI), the removal potential from aqueous solutions of the biochars tested herein (BC: $48.6 \mathrm{mg} \mathrm{g}^{-1}$, MBC: $53.2 \mathrm{mg} \mathrm{g}^{-1}$ ) was significantly higher than those of eucalyptus wood- $\left(27.2 \mathrm{mg} \mathrm{g}^{-1}\right),{ }^{48}$ fungus pleurotus ostreatus- $\left(19.4 \mathrm{mg} \mathrm{g}^{-1}\right)^{49}$ and magnetic chitosan- $\left(42 \mathrm{mg} \mathrm{g}^{-1}\right)^{51}$ derived bichars. However, BC and MBC showed the lower $\mathrm{U}(\mathrm{vr})$ removal potential as compared to activated cactus fibre $\left(214 \mathrm{mg} \mathrm{g}^{-1}\right) . .^{51}$

The values of $\Delta H^{0}$ and $\Delta S^{0}$ were obtained by plotting the $\ln \mathrm{K}$ vs. 1/T (Fig. 6). Unlike $\mathrm{Pb}(\mathrm{II})$ that showed similar maximum adsorption capacities at $328 \mathrm{~K}$ for both biochar samples (BC: $125 \mathrm{mg} \mathrm{g}^{-1}$ and MBC: $129 \mathrm{mg} \mathrm{g}^{-1}$ ), the adsorption of U(vI) was significantly enhanced over MBC (BC: 64.0 and MBC: $118 \mathrm{mg}$ $\mathrm{g}^{-1}$ ). This could be explained by the energy of the adsorption system increasing with temperature (Table $3, \Delta \mathrm{S}^{0}$ and $\Delta H^{0}$ of MBC higher than those of $\mathrm{BC}$, and the values of $\mathrm{U}(\mathrm{vI})$ higher than those of $\mathrm{Pb}(\mathrm{II})$ ), and the adsorption efficiency increasing as a result. The negative values of $\Delta G^{0}$ (from -6.13 to $2.20 \mathrm{KJ}$ $\mathrm{mol}^{-1}$ ) suggested the adsorption of $\mathrm{Pb}(\mathrm{II})$ and $\mathrm{U}(\mathrm{VI})$ on $\mathrm{BC}$ and MBC to be a spontaneous process being more favored at high temperatures. ${ }^{1}$ The positive value of $\Delta S^{0}$ revealed an increase in

Table 4 Comparison of the maximum uptake of $\mathrm{Pb}(॥)$ and $\mathrm{U}(\mathrm{VI})$ on various modified biochar adsorbents

\begin{tabular}{|c|c|c|c|c|c|c|}
\hline Adsorbate & Feedstock & $\begin{array}{l}\text { Pyrolysis } \\
\text { temperature (K) }\end{array}$ & Modified materials & $\begin{array}{l}\text { BET surface } \\
\text { area, }\left(\mathrm{m}^{2} \mathrm{~g}^{-1}\right)\end{array}$ & $\begin{array}{l}Q_{\max }^{a} \\
\left(\mathrm{mg} \mathrm{g}^{-1}\right)\end{array}$ & Reference \\
\hline \multirow[t]{5}{*}{$\mathrm{Pb}(\mathrm{II})$} & Oak wood & 673 & $\mathrm{Fe}^{2+} / \mathrm{Fe}^{3+}$ plus $\mathrm{SO}_{4}{ }^{2-}$ solution & 2.04 & 10.1 & Mohan et al. $(2014)^{43}$ \\
\hline & Bamboo & - & Fine sized ZVI & - & 25.1 & Zhou et al. $(2014)^{44}$ \\
\hline & Pine bark & 1223 & Ferrite $\left(\mathrm{CoFe}_{2} \mathrm{O}_{4}\right)$ & - & 25.3 & Harikishore et al. $(2014)^{45}$ \\
\hline & Romchar & 773 & Magnetite/maghemite & 219 & 17.7 & Han et al. $(2015)^{46}$ \\
\hline & Rice husk & 773 & $\mathrm{Fe}^{2+} / \mathrm{Fe}^{3+}$ plus $\mathrm{SO}_{4}^{2-}$ solution & 109 & 110 & In this study \\
\hline \multirow[t]{3}{*}{$\mathrm{U}(\mathrm{vI})$} & Eucalyptus wood & 673 & - & 20 & 27.2 & Mishra et al. $(2017)^{48}$ \\
\hline & $\begin{array}{l}\text { Fungus pleurotus } \\
\text { ostreatus }\end{array}$ & 343 & - & - & 19.4 & Zhao et al. $(2016)^{49}$ \\
\hline & Magnetic chitosan & - & Magnetite powder & - & 42 & $\begin{array}{l}\text { Stopa and Yamaura } \\
(2010)^{50}\end{array}$ \\
\hline
\end{tabular}

${ }^{a} Q_{\text {max }}$ the maximum $\mathrm{Pb}(\mathrm{II})$ and $\mathrm{U}(\mathrm{VI})$ adsorption capacities of biochar in the water solution at $298 \mathrm{~K}$. It was calculated based on the Langmuir model. 

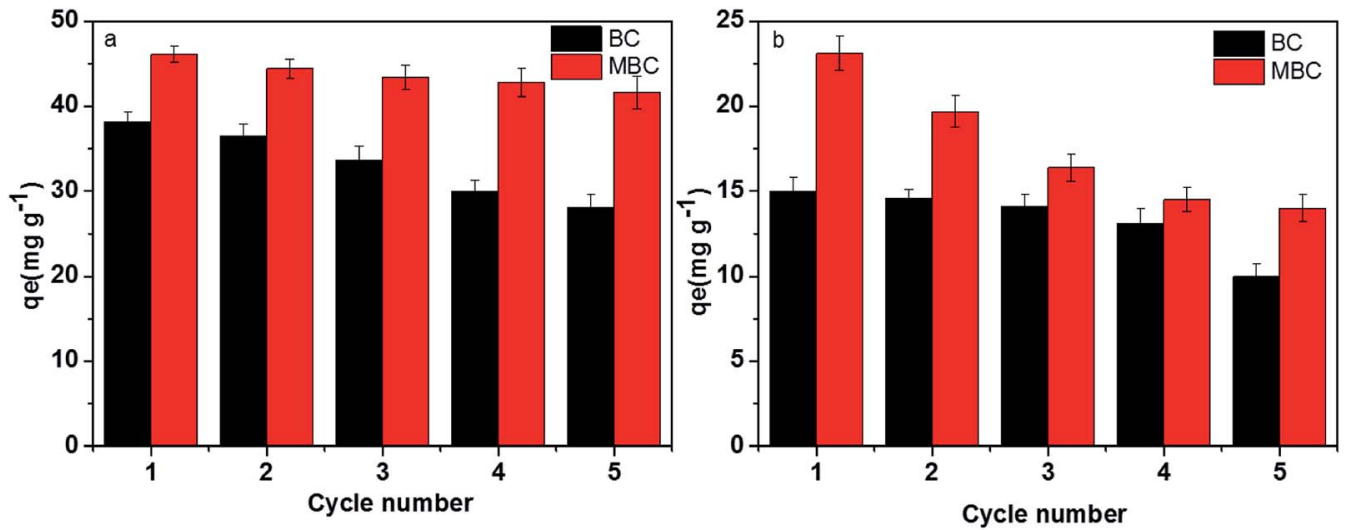

Fig. 7 Recycling studies of $\mathrm{BC}(\mathrm{a})$ and $\mathrm{MBC}(\mathrm{b})$ for the adsorption of $\mathrm{Pb}(॥)$ and $\mathrm{U}(\mathrm{VI})$.

the randomness of the solid/solution interface..$^{52}$ The positive value of $\Delta H^{0}$ revealed the adsorption of $\mathrm{Pb}(\mathrm{II})$ and $\mathrm{U}(\mathrm{vI})$ on $\mathrm{BC}$ and $\mathrm{MBC}$ to be endothermic processes, while the low $\Delta H^{0}$ value could be indicative of a prevalent physical adsorption. High $\Delta H^{0}$ values are indicative of highly energetic processes involving the collapse of the hydration sheath of metal ions with molecular water and the formation of some chemical bonds between the metal ions. ${ }^{53}$

\section{Recycling of the biochars}

The economic value of $\mathrm{BC}$ and $\mathrm{MBC}$ was evaluated by performing a recycling study involving repetitive adsorptiondesorption cycles. As shown in Fig. 7, the adsorption capacities of $\mathrm{Pb}$ (II) and $\mathrm{U}(\mathrm{VI})$ on $\mathrm{BC}$ decreased from 38.1 to $25.3 \mathrm{mg} \mathrm{g}^{-1}$ and from 15.8 to $9.76 \mathrm{mg} \mathrm{g}^{-1}$, respectively, after five consecutive adsorption-desorption cycles. In contrast, the adsorption capacity of $\mathrm{Pb}$ (II) on MBC only slightly decreased (from 47.3 to $40.8 \mathrm{mg} \mathrm{g}^{-1}$ ) after five consecutive adsorption-desorption cycles, whereas that of $\mathrm{U}(\mathrm{vI})$ significantly dropped from 28.1 to $13.7 \mathrm{mg} \mathrm{g}^{-1}$. Despite the decrease in the adsorption capacities of $\mathrm{Pb}(\mathrm{II})$ and $\mathrm{U}(\mathrm{VI})$ on $\mathrm{BC}$ and $\mathrm{MBC}$, the magnetically modified biochar showed a relatively high adsorption ability towards these metals and a good reusability behavior for $\mathrm{Pb}(\mathrm{II})$ and $\mathrm{U}(\mathrm{VI})$ removal. Moreover, the amount of iron ions leaching from MBC in the solution was only $0.003-0.014 \mathrm{mg} \mathrm{L}^{-1}$ from the first cycle to the third cycle, and almost no iron ions was leached from MBC at the fourth cycle and the fifth cycle, which indicated the loaded iron on biochar was real stable. ${ }^{18}$ The observed decrease in the adsorption capacity could be explained in terms of: (1) a reduction in the surface area and pore volume of the biochar samples; (2) the presence of weaker functional groups; and 3) leaching of $\mathrm{Fe}_{3} \mathrm{O}_{4}$ on the surficial layer of biochar during the soaking process with a $\mathrm{HCl}$ solution(Fig. 8)..$^{24,54}$ The larger decrease in the adsorption efficiency of $\mathrm{U}(\mathrm{vI})$ on $\mathrm{MBC}$ as compared to $\mathrm{Pb}$ (II) further confirmed the different adsorption behavior of both ions (i.e., physisorption for $\mathrm{Pb}$ (II) and chemisorption for $\mathrm{U}(\mathrm{vI}))$. Thus, the chemisorption process was more affected by the $\mathrm{HCl}$ soaking regeneration treatment of $\mathrm{MBC}$ as compared to physisorption.

\section{Adsorption mechanism}

To investigate the adsorption mechanism of $\mathrm{Pb}$ (II) and $\mathrm{U}(\mathrm{vI})$ on BC and MBC, FTIR, XRD, and XPS analyses were conducted before and after adsorption (Fig. 9 and 10). A band at $3420 \mathrm{~cm}^{-1}$ was observed and ascribed to the stretching vibration of $\mathrm{O}-\mathrm{H}$ of both biochars. ${ }^{49,55}$ The peaks at $c a .2360,1620$, and $1068 \mathrm{~cm}^{-1}$ corresponded to the $\mathrm{N}-\mathrm{H}$ bond, the stretching of the $\mathrm{C}=\mathrm{C}$ bond, and the $\mathrm{C}-\mathrm{O}-\mathrm{C}$ vibration of $\mathrm{BC}$ and $\mathrm{MBC}$, respectively. ${ }^{55,56}$ The main band of the FTIR spectra of BC and MBC was observed at $584 \mathrm{~cm}^{-1}$ and corresponded to the $\mathrm{Fe}-\mathrm{O}$ bond. ${ }^{54}$ Numerous peaks appeared or disappeared after adsorption of $\mathrm{Pb}(\mathrm{II})$ and $\mathrm{U}(\mathrm{VI})$ on $\mathrm{BC}$ and MBC. The change in the peak near $2240 \mathrm{~cm}^{-1}$ was produced by the vibration of the $\mathrm{NO}_{3}{ }^{-}$ion in $\mathrm{Pb}\left(\mathrm{NO}_{3}\right)_{2}$ and $\mathrm{U}\left(\mathrm{NO}_{3}\right)_{6}$, thereby revealing the presence of these species formed by ion exchange after adsorption of $\mathrm{Pb}(\mathrm{II})$ and $\mathrm{U}(\mathrm{VI})$. Compared to $\mathrm{BC}$ after adsorption, the signals corresponding to the surface function groups of MBC were slightly shifted. Thus, the signal at $1558-1566 \mathrm{~cm}^{-1}$ shifted to $1695-1701 \mathrm{~cm}^{-1}$ after $\mathrm{Pb}$ (II) and $\mathrm{U}$ (VI) adsorption on $\mathrm{MBC}$, thereby confirming the formation of metal chelation complexes on this sample, in line with the results reported by Samsuri et al. ${ }^{36}$ and Trakal et al. ${ }^{23}$

The XRD patterns further confirmed the different adsorption mechanisms (Fig. 9c and d). The diffraction peaks of BC slightly

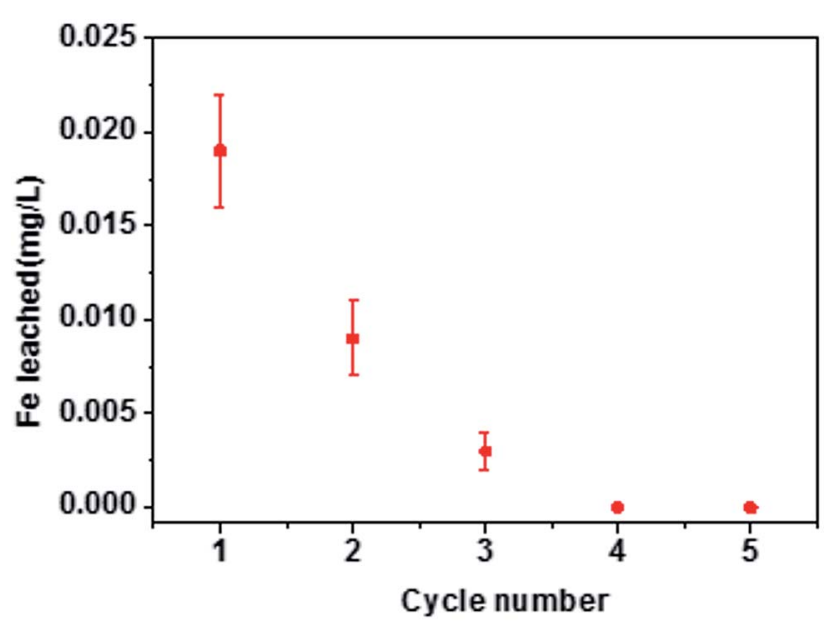

Fig. 8 Stability of iron particles aggregated on MBC. 

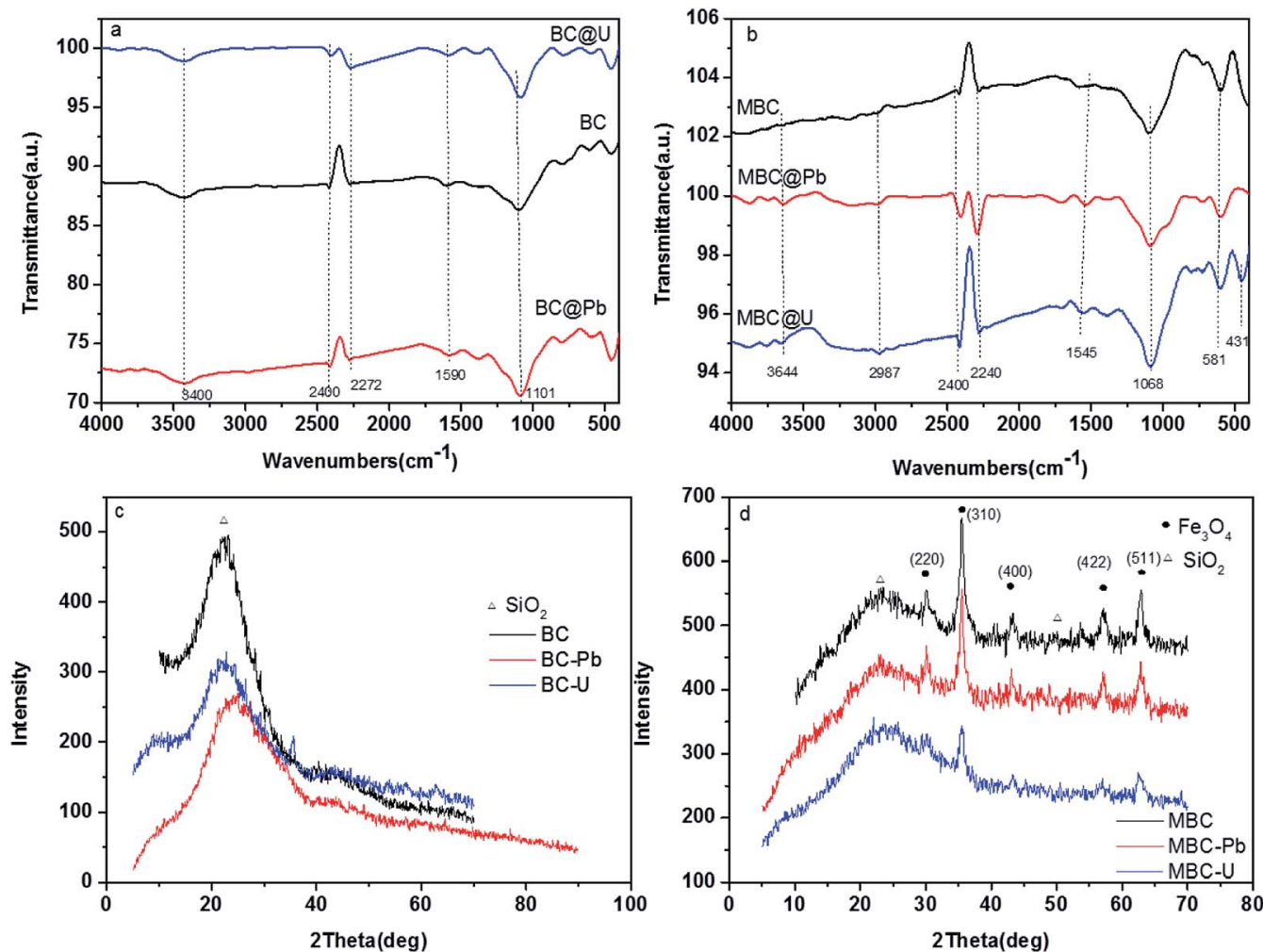

Fig. 9 FTIR spectra and XRD patterns of $\mathrm{BC}$ before and after adsorption of $\mathrm{Pb}(\mathrm{I})$ and $\mathrm{U}(\mathrm{VI})$ ( $\mathrm{a}$ and $\mathrm{c}$, respectively) and $\mathrm{MBC}$ before and after adsorption of $\mathrm{Pb}(॥)$ and $\mathrm{U}(\mathrm{VI})$ (b and d, respectively).

shifted after adsorption, thereby potentially suggesting a very stable crystal structure of this material. Additionally, the XRD results suggested that the adsorption process took place on the outer surface of $\mathrm{BC}$ mostly via physical interactions. With regard to MBC, numerous peaks disappeared and weakened after the adsorption of $\mathrm{Pb}(\mathrm{II})$ and $\mathrm{U}(\mathrm{VI})$. These results might indicate that
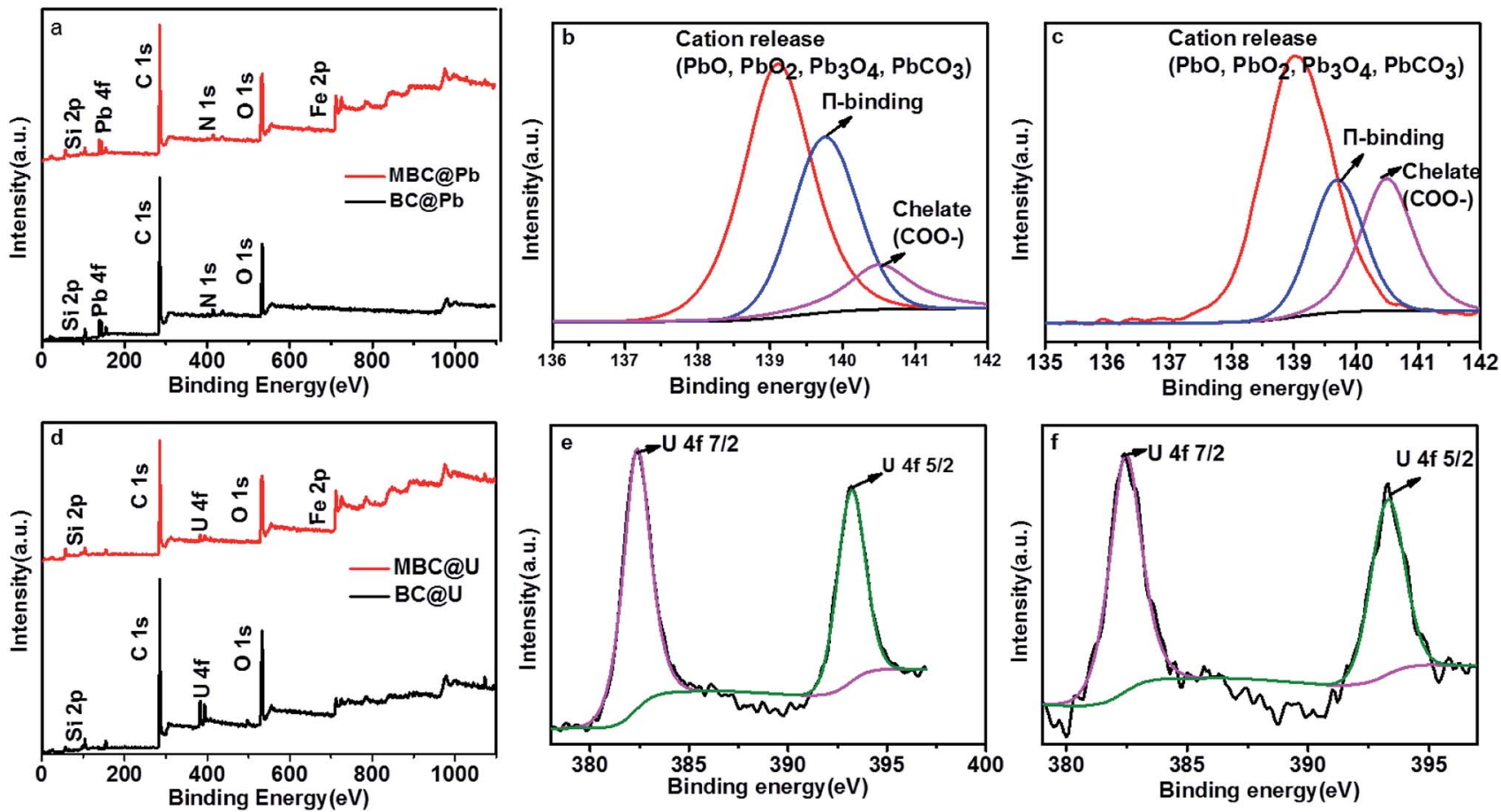

Fig. 10 XPS wide scan ( $a$ and $d$ ) and high resolution $\mathrm{Pb} 4 \mathrm{f}(\mathrm{b}$ and $\mathrm{c}$ ) and $\mathrm{U} 4 \mathrm{f}$ (e and f) spectra of $\mathrm{BC}$ and MBC, respectively. 
the adsorption of $\mathrm{Pb}(\mathrm{II})$ and $\mathrm{U}(\mathrm{VI})$ on $\mathrm{MBC}$ was carried out via surface complexes formation and chemical precipitation process. ${ }^{50}$ Moreover, compared to $\mathrm{Pb}$ (II), the intensity of the peaks corresponding to $\mathrm{U}(\mathrm{vI})$ on $\mathrm{BC}$ and $\mathrm{MBC}$ decreased in all cases, thereby indicating the prevalence of chemical adsorption processes. In contrast, $\mathrm{Pb}$ (II) was mainly bonded to the biochar sample via physical adsorption processes.

Finally, XPS measurements were conducted to further analyze the adsorption mechanism (Fig. 10). As shown in Fig. 8, $\mathrm{a} \mathrm{Pb} 4 \mathrm{f}$ band with three different binding energies in the range of 137-142 eV was observed for BC and MBC. The presence of a main peak at $-139 \mathrm{eV}(\mathrm{Pb}-\mathrm{O})$ revealed that the predominant adsorption mechanisms were cation release and/or precipitation. ${ }^{57}$ The peak at $139.6 \mathrm{eV}$ ( $\pi$-binding) suggested another adsorption mechanism (i.e., surface adsorption). The intensity of this $\pi$-binding signal was slightly higher for $\mathrm{MBC}$ as compared to $\mathrm{BC}$, and this could be attributed to the presence of Fe oxides on the surface of MBC. ${ }^{21}$ The peak at $140.5 \mathrm{eV}$ (chelate $\mathrm{COO}-)$ of $\mathrm{Pb}(\mathrm{II})$ suggested the existence of an additional adsorption mechanism (i.e., complexation with $\mathrm{Pb}(\mathrm{II}))^{23}$ The higher intensity of this chelate COO- signal for MBC was indicative of an enhanced complexation adsorption after magnetic modification because of the presence of Fe oxides in the structure of MBC. ${ }^{23}$ As shown in Fig. 8, the $\mathrm{U} 4 \mathrm{f}$ band of $\mathrm{BC}$ and $\mathrm{MBC}$ (located between the $\mathrm{C} 1 \mathrm{~s}$ and $\mathrm{O}$ 1s bands) involved two different binding energies (382 and $393 \mathrm{eV}$ ) corresponding to the $\mathrm{U} 4 \mathrm{f}_{7 / 2}$ and $\mathrm{U} 4 \mathrm{f}_{5 / 2}$ transitions, respectively. According to the FTIR results, the peaks of $\mathrm{U} 4 \mathrm{f}$ can be ascribed to the formation of $\mathrm{C}-\mathrm{O}-\mathrm{UO}_{2}{ }^{+}$and $\mathrm{COO}-\mathrm{UO}_{2}{ }^{+}$species via surface complex formation and precipitation processes.

\section{Conclusion}

The adsorption of $\mathrm{Pb}(\mathrm{II})$ and $\mathrm{U}(\mathrm{VI})$ on biochar and the reusability of this material was greatly improved via magnetic modification, especially for $\mathrm{Pb}$ (II) removal. The $\mathrm{pH}$ and the temperature significantly affected the adsorption behavior of $\mathrm{Pb}$ (II) and $\mathrm{U}(\mathrm{VI})$ on $\mathrm{BC}$ and $\mathrm{MBC}$. The adsorption experimental data were well fitted by Langmuir isotherm and pseudo-second-order kinetic models. The removal of $\mathrm{U}(\mathrm{vI})$ was significantly enhanced over MBC as compared to $\mathrm{Pb}(\mathrm{II})$. Based on the FTIR, XRD, and XPS results, electrostatic interaction and surface complexation were separately suggested as the main mechanisms for the adsorption of $\mathrm{Pb}(\mathrm{II})$ and $\mathrm{U}(\mathrm{VI})$ on biochars. Ion exchange and complexation were noticeably improved after impregnation of Fe oxide on BC. The resultant MBC material can be used as a potential adsorbent for $\mathrm{Pb}(\mathrm{II})$ and $\mathrm{U}(\mathrm{VI})$. The recycling study confirmed the good regeneration properties and stability of MBC, making it suitable for the removal of $\mathrm{Pb}(\mathrm{II})$ and $\mathrm{U}(\mathrm{VI})$ species in solution.

\section{Conflicts of interest}

There are no conflicts to declare.

\section{Acknowledgements}

The study was funded by projects of Beijing Natural Science Foundation of China (No. 8152028) and the Fundamental Research Funds for the Central Universities of China (No. 2018MS047). The research is also supported by the Open Issue of Beijing Key Laboratory of New Technique in Agricultural Application (No. 5076516003/051).

\section{Notes and references}

1 E. Agrafioti, D. Kalderis and E. Diamadopoulos, J. Environ. Manage., 2014, 133, 309-314.

2 A. Bogusz, P. Oleszczuk and R. Dobrowolski, Bioresour. Technol., 2015, 196, 540-549.

3 Y. Yang, Z. Wei, X. Zhang, X. Chen, D. Yue, Q. Yin, L. Xiao and L. Yang, Bioresour. Technol., 2014, 171, 227-232.

4 Y. Wu, Energy Policy, 2016, 101, 484-491.

5 R. Kumar, M. Rani, H. Gupta and B. Gupta, Chem. Speciation Bioavailability, 2014, 26, 200-209.

6 S. J. Wang, W. Guo, F. Gao and R. Yang, R. Soc. Open Sci., 2017, 4, 170402.

7 F. Wang, X. Lu and X. Y. Li, J. Hazard. Mater., 2016, 308, 7583.

8 R. Hu, D. D. Shao and X. K. Wang, Polym. Chem., 2014, 5, 6207-6215.

9 World Health Organization, Guidelines for Drinking-Water Quality, 4th edn, 2011, p. 430.

10 G. J. Ji, G. R. Zhu, X. H. Wang, Y. L. Wei, J. S. Yuan and C. J. Gao, Sep. Purif. Technol., 2017, 174, 455-465.

11 P. A. Kavaklı, N. Seko, M. Tamada and G. Guven, J. Appl. Polym. Sci., 2007, 105, 1551-1558.

12 R. Sahraei, Z. Sekhavat Pour and M. Ghaemy, Journal of Cleaner Production, 2017, 142, 2973-2984.

13 N. Sahiner, Water, Air, Soil Pollut., 2014, 225, 1982.

14 D. Sud, G. Mahajan and M. P. Kaur, Bioresour. Technol., 2008, 99, 6017-6027.

15 H. A. Hegazi, HBRC Journal, 2013, 9, 276-282.

16 T. M. Abdel-Fattah, M. E. Mahmoud, S. B. Ahmed, M. D. Huff, J. W. Lee and S. Kumar, J. Ind. Eng. Chem., 2015, 22, 103-109.

17 W. Guo, Y. J. Ai, B. Men and S. J. Wang, Int. J. Environ. Sci. Technol., 2017, 14, 1889-1896.

18 Lalhmunsiama, P. L. Gupta, H. Jung, D. Tiwari, S. H. Kong and S. M. Lee, J. Taiwan Inst. Chem. Eng., 2016, 71, 206-213.

19 L. Beesley, E. Moreno-Jimenez, J. L. Gomez-Eyles, E. Harris, B. Robinson and T. Sizmur, Environ. Pollut., 2011, 159, 3269-3282.

20 R. Cai, X. Wang, X. Ji, B. Peng, C. Tan and X. Huang, J. Environ. Manage., 2017, 187, 212-219.

21 R. D. Ambashta and M. Sillanpää, J. Hazard. Mater., 2010, 180, 38-49.

22 J. G. Shang, J. C. Pi, M. Z. Zong, Y. R. Wang, W. H. Li and Q. H. Liao, J. Taiwan Inst. Chem. Eng., 2016, 68, 289-294.

23 L. Trakal, V. Veselska, I. Safarik, M. Vitkova, S. Cihalova and M. Komarek, Bioresour. Technol., 2016, 203, 318-324. 
24 S. B. Liu, B. Y. Huang, L. Y. Chai, Y. G. Liu, G. M. Zeng, X. Wang, W. Zeng, M. R. Shang, J. Q. Deng and Z. Zhou, RSC Adv., 2017, 7, 10891-10900.

25 P. Y. Wang, X. X. Wang, S. J. Yu, Y. D. Zou, J. Wang, Z. S. Chen, N. S. Alharbi, A. Alsaedi, T. Hayat, Y. Chen and X. K. Wang, Chem. Eng. J., 2016, 306, 280-288.

26 K. Siriworarat, V. Deerattrakul, P. Dittanet and P. Kongkachuichay, Journal of Cleaner Production, 2017, 142, 1234-1243.

27 W. Yao, S. J. Yu, J. Wang, Y. D. Zou, S. Lu, Y. J. Ai, N. S. Alharbi, A. Alsaedi, T. Hayat and X. K. Wang, Chem. Eng. J., 2017, 307, 476-486.

28 S. H. Huang and D. H. Chen, J. Hazard. Mater., 2009, 163, 174-179.

29 W. Guo, S. L. Huo, J. L. Feng and X. F. Lu, J. Taiwan Inst. Chem. Eng., 2017, 78, 265-271.

30 D. Mohan, P. Singh, A. Sarswat, P. H. Steele and C. U. P. Pittman Jr, J. Colloid Interface Sci., 2015, 448, 238250.

31 X. Q. Cui, S. Y. Fang, Y. Q. Yao, T. Q. Li, Q. J. Ni, X. E. Yang and Z. L. He, Sci. Total Environ., 2016, 562, 517-525.

32 T. D. Nguyen, N. H. Phan, M. H. Do and K. T. Ngo, J. Hazard. Mater., 2011, 185, 653-661.

33 A. A. Alqadami, M. A. Khan, M. Otero, O. Marta, R. S. Masoom, H. J. Byong and M. B. Khalid, J. Cleaner Prod., 2018, 178, 293-304.

34 G. X. Wang, J. Yang, J. Park, X. L. Gou, B. Wang, H. Liu and J. Yao, J. Phys. Chem. C, 2008, 112, 8192-8195.

35 S. Vilvanathan and S. Shanthakumar, Process Saf. Environ. Prot., 2015, 96, 98-110.

36 A. W. Samsuri, F. Sadegh-Zadeh and B. J. Seh-Bardan, Int. J. Environ. Sci. Technol., 2014, 11, 967-976.

37 P. Srinivasan, A. K. Sarmah, R. Smernik, O. Das, M. Farid and W. Gao, Sci. Total Environ., 2015, 521-513, 495-505.

38 M. R. Chandraiah, Alexandria Eng. J., 2016, 55, 619-625.

39 M. Zhang, B. Gao, S. Varnoosfaderani, A. Hebard, Y. Yao and M. Inyang, Bioresour. Technol., 2013, 130, 457-462.
40 A. Ashry, E. H. Bailey, S. R. N. Chenery and S. D. Young, J. Hazard. Mater., 2016, 320, 55-65.

41 L. Hadjittofi and I. Pashalidis, Desalin. Water Treat., 2016, 57, 27864-27868.

42 Z. B. Zhang, X. B. Cao, P. Liang and Y. H. Liu, J. Radioanal. Nucl. Chem., 2013, 295, 1201-1208.

43 D. Mohan, H. Kumar, A. Sarswat, M. Alexandre-Franco and C. U. Pittman Jr, Chem. Eng. J., 2014, 236, 513-528.

44 Y. Zhou, B. Gao, A. R. Zimmerman, H. Chen, M. Zhang and X. Cao, Bioresour. Technol., 2014, 152, 538-542.

45 D. Harikishore, K. Reddy and S. M. Lee, Colloids Surf., A, 2014, 454, 96-103.

46 Z. Han, B. Sani, W. Mrozik, M. Obst, B. Beckingham, H. K. Karapanagioti and D. Werner, Water Res., 2015, 70, 394-403.

47 J. Ifthikar, W. Jia and Q. Wang, Bioresour. Technol., 2017, 238, 399-406.

48 V. Mishra, M. K. Sureshkumar, N. Gupta and C. P. Kaushik, Water, Air, Soil Pollut., 2017, 228, 309.

49 C. Zhao, J. Liu, H. Tu, F. Li, X. Li and J. Yang, Environ. Sci. Pollut. Control Ser., 2016, 23, 24846-24856.

50 L. C. B. Stopa and M. Yamaura, Int. J. Energy Res., 2010, 5, 283-289.

51 L. Hadjittofi and I. Pashalidis, J. Radioanal. Nucl. Chem., 2015, 304, 897-904.

52 P. Maneechakr and S. Karnjanakom, J. Chem. Thermodyn., 2017, 106, 104-112.

53 L. Wang, W. Yan, C. He, H. Wen, Z. Cai, Z. X. Wang, Z. Z. Chen and W. F. Liu, Appl. Surf. Sci., 2018, 433, 222-231.

54 H. Jin, S. Capareda, Z. Chang, J. Gao, Y. Xu and J. Zhang, Bioresour. Technol., 2014, 169, 622-629.

55 P. Devi, Bioresour. Technol., 2014, 169, 525-531.

56 T. Chen, Z. Zhou, R. Han, R. Meng, H. Wang and W. Lu, Chemosphere, 2015, 134, 286-293.

57 Y. F. Xi, M. Mallavarapu and R. Naidu, Mater. Res. Bull., 2010, 45, 1361-1367. 